\title{
Individualization of Irinotecan Treatment: A Review of Pharmacokinetics, Pharmacodynamics, and Pharmacogenetics
}

\author{
Femke M. de Man' ${ }^{1}$ Andrew K. L. Goey ${ }^{2}$ Ron H. N. van Schaik ${ }^{3}$. \\ Ron H. J. Mathijssen ${ }^{1} \cdot$ Sander Bins ${ }^{1}$
}

Published online: 8 March 2018

(C) The Author(s) 2018. This article is an open access publication

\begin{abstract}
Since its clinical introduction in 1998, the topoisomerase I inhibitor irinotecan has been widely used in the treatment of solid tumors, including colorectal, pancreatic, and lung cancer. Irinotecan therapy is characterized by several dose-limiting toxicities and large interindividual pharmacokinetic variability. Irinotecan has a highly complex metabolism, including hydrolyzation by carboxylesterases to its active metabolite $\mathrm{SN}-38$, which is 100- to 1000 -fold more active compared with irinotecan itself. Several phase I and II enzymes, including cytochrome P450 (CYP) 3A4 and uridine diphosphate glucuronosyltransferase (UGT) 1A, are involved in the formation of inactive metabolites, making its metabolism prone to environmental and genetic influences. Genetic variants in the DNA of these enzymes and transporters could predict a part of the drug-related toxicity and efficacy of treatment, which has been shown in retrospective and prospective trials and meta-analyses. Patient characteristics, lifestyle and comedication also influence irinotecan pharmacokinetics. Other factors, including dietary restriction, are currently being studied. Meanwhile, a more tailored approach to prevent excessive toxicity and optimize efficacy is warranted. This review provides an updated
\end{abstract}

Sander Bins

s.bins@erasmusmc.nl

1 Department of Medical Oncology, Erasmus MC Cancer Institute, 's-Gravendijkwal 230, 3015 Rotterdam, The Netherlands

2 Department of Hospital Pharmacy, Erasmus Medical Center, Rotterdam, The Netherlands

3 Department of Clinical Chemistry, Erasmus Medical Center, Rotterdam, The Netherlands overview on today's literature on irinotecan pharmacokinetics, pharmacodynamics, and pharmacogenetics.

\section{Key Points}

Irinotecan metabolism is complex due to the involvement of many enzymes and transporters, and is therefore prone to drug-drug interactions. Prior to starting with irinotecan chemotherapy, patients should be evaluated for possible interactions with comedication.

Single nucleotide polymorphisms in several drug metabolizing enzymes (e.g. uridine diphosphate glucuronosyltransferase [UGT] 1A1, UGT1A7, UGT1A9) and drug transporters (e.g. ATP-binding cassette $[\mathrm{ABC}] \mathrm{B} 1, \mathrm{ABCC} 1)$ have been reported to be significantly associated with irinotecan toxicity. Caucasian patients should be screened for $U G T 1 A 1 * 28$ and Asian patients for $U G T 1 A 1 * 6$ in advance of irinotecan treatment as these polymorphisms are common in those populations and dosing can be personalized if UGT1A1 functioning is constitutionally altered.

Despite existing genotype-based dosing guidelines, upfront UGT1A1 genotyping is not yet routinely performed in patients starting with irinotecan chemotherapy. 


\section{Introduction}

Irinotecan (CPT-11) is a camptothecin derivative that demonstrates anticancer activity in many solid tumors. Currently, it is widely used in the treatment of colorectal, pancreatic, and lung cancer. Irinotecan is the prodrug for SN-38, which inhibits topoisomerase-I, an enzyme involved in DNA replication [1, 2]. $\mathrm{SN}-38$ is 100- to 1000 -fold more cytotoxic than irinotecan, and its exposure is highly variable [3]. SN-38 is inactivated by further enzymatic conversion into SN-38 glucuronide (SN-38G).

\section{Pharmacokinetics}

\subsection{Distribution}

Irinotecan is a hydrophilic compound with a large volume of distribution estimated at almost $400 \mathrm{~L} / \mathrm{m}^{2}$ at steady state [4]. At physiological $\mathrm{pH}$, the lactone-ring of irinotecan and SN-38 can be hydrolyzed to a carboxylate isoform (Fig. 1). Consequently, a pH-dependent equilibrium between these forms exists [5]. As only the lactone form has antitumor activity, a small change in $\mathrm{pH}$ could alter the pharmacokinetics and efficacy of irinotecan [6]. However in plasma the carboxylate form of irinotecan and the lactone form of SN-38 dominate [7, 8]. This could be explained by a higher tissue distribution of irinotecan lactone and the preferential binding of SN-38 lactone to plasma proteins
[4, 9]. Conversion of irinotecan lactone to carboxylate within the circulation is rapid, with an initial half-life of between 9 and $14 \mathrm{~min}$, which results in a 50\% reduction in irinotecan lactone concentration after $2.5 \mathrm{~h}$, compared with end of infusion (66 vs. 35\%) [4, 7, 8].

After the end of drug infusion, a rapid decrease in irinotecan plasma concentrations is seen. Peak concentrations of SN-38 are reached within $2 \mathrm{~h}$ after infusion [8]. Irinotecan is assumed to exhibit linear pharmacokinetics because of the correlation between dose and systemic exposure, which is highly variable between patients [8]. In plasma, the majority of irinotecan and SN-38 is bound to albumin, which has a stronger binding capacity for the more hydrophobic active metabolite, and albumin also stabilizes the lactone forms of irinotecan and SN-38 [10]. In blood, SN-38 is almost completely bound, with twothirds located in platelets and, predominantly, red blood cells [11]. The binding constant of SN-38 with erythrocytes is almost 15-fold higher than that of irinotecan [11].

Thus far, several population pharmacokinetic models of irinotecan have been developed. All models confirmed the large interindividual variability in pharmacokinetic parameters of approximately $30 \%$. In general, a threecompartmental model for irinotecan and a two-compartmental model for $\mathrm{SN}-38$ is assumed [4, 12-16]. A mean SN-38 distribution half-life was estimated to be very short (approximately $8 \mathrm{~min}$ ) [13]. Several models showed a second peak in the SN-38 plasma area under the curve (AUC), which was explained by an enterohepatic re-

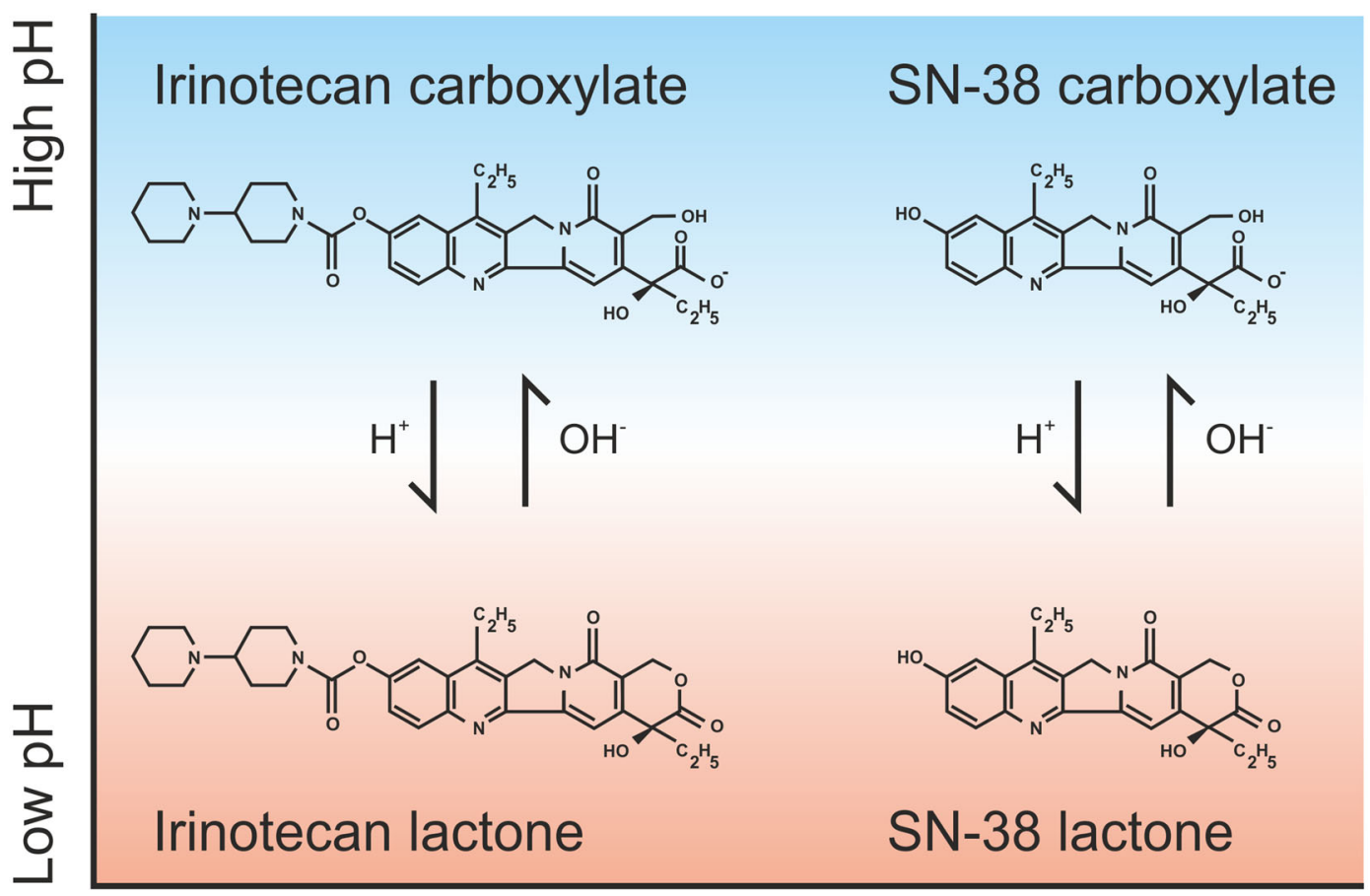

Fig. 1 pH-dependent equilibrium of irinotecan and SN-38 isoforms 
circulation of SN-38. SN-38 is reabsorbed after intestinal deconjugation of $\mathrm{SN}-38 \mathrm{G}$ by (bacterial) $\beta$-glucuronidases [15]. Alternatively, release of SN-38 from erythrocytes has also been proposed to cause this second plasma peak [17].

\subsection{Metabolism}

\subsubsection{Metabolism by Carboxylesterases and Butyrylcholinesterase}

The prodrug irinotecan is hydrolyzed into the active metabolite $\mathrm{SN}-38$ by two isoforms of carboxylesterases (CES1 and 2) and butyrylcholinesterase in the human body (Fig. 2) [18, 19]. CES1 and CES2 are localized in liver, colon, kidney, and blood cells, while butyrylcholinesterase is mainly found in plasma [20]. Conversion by these esterases mainly occurs intrahepatically and is a relatively slow and inefficient process as only $2-5 \%$ of irinotecan is converted into SN-38 [12, 18]. CES2 has a 12.5-fold higher affinity for irinotecan than CES1 and is therefore the predominant enzyme in this conversion [21-23]. In addition, this process also occurs in blood, where butyrylcholinesterase has a sixfold higher activity than CES [20]. After conversion, $\mathrm{SN}-38$ is actively transported into the liver by the organic anion transporting polypeptide (OATP) 1B1 transporter (Fig. 2) [24].

Many studies have investigated intratumoral CES activity, by which irinotecan can be activated at the site of action. Indeed, the amount of CES activity could be related to irinotecan efficacy, although preclinical work showed conflicting results [25-30]. Many preclinical studies have been performed to selectively increase the intratumoral CES activity with a virus or engineered stem cells, thereby aiming to increase irinotecan efficacy [31-38]. Although a few studies could indeed reverse irinotecan resistance in vitro and in mice, this mechanism has not yet been investigated in a clinical setting.

To our knowledge, no clinically relevant drug-drug interactions (DDIs) involving CES have been reported for irinotecan, although both inhibitors and inducers of CES have been described, which could potentially influence the rate of irinotecan conversion to SN-38 [39].

\subsubsection{Metabolism by Uridine Diphosphate Glucuronosyltransferases}

$\mathrm{SN}-38$ is inactivated via glucuronidation to $\mathrm{SN}-38 \mathrm{G}$ by uridine diphosphate glucuronosyltransferase (UGT) and excreted into the bile [40, 41]. Several UGT subtypes are involved in the hepatic (UGT1A1, UGT1A9) and extrahepatic (UGT1A1, UGT1A7, UGT1A10) conversion of SN-38, of which UGT1A1, UGT1A7 and UGT1A9 are the major isoenzymes [42-46]. SN-38G is formed almost directly after $\mathrm{SN}-38$ formation, explaining the short halflife of SN-38 [47]. Plasma concentrations of SN-38G are the highest among all irinotecan metabolites, suggesting a

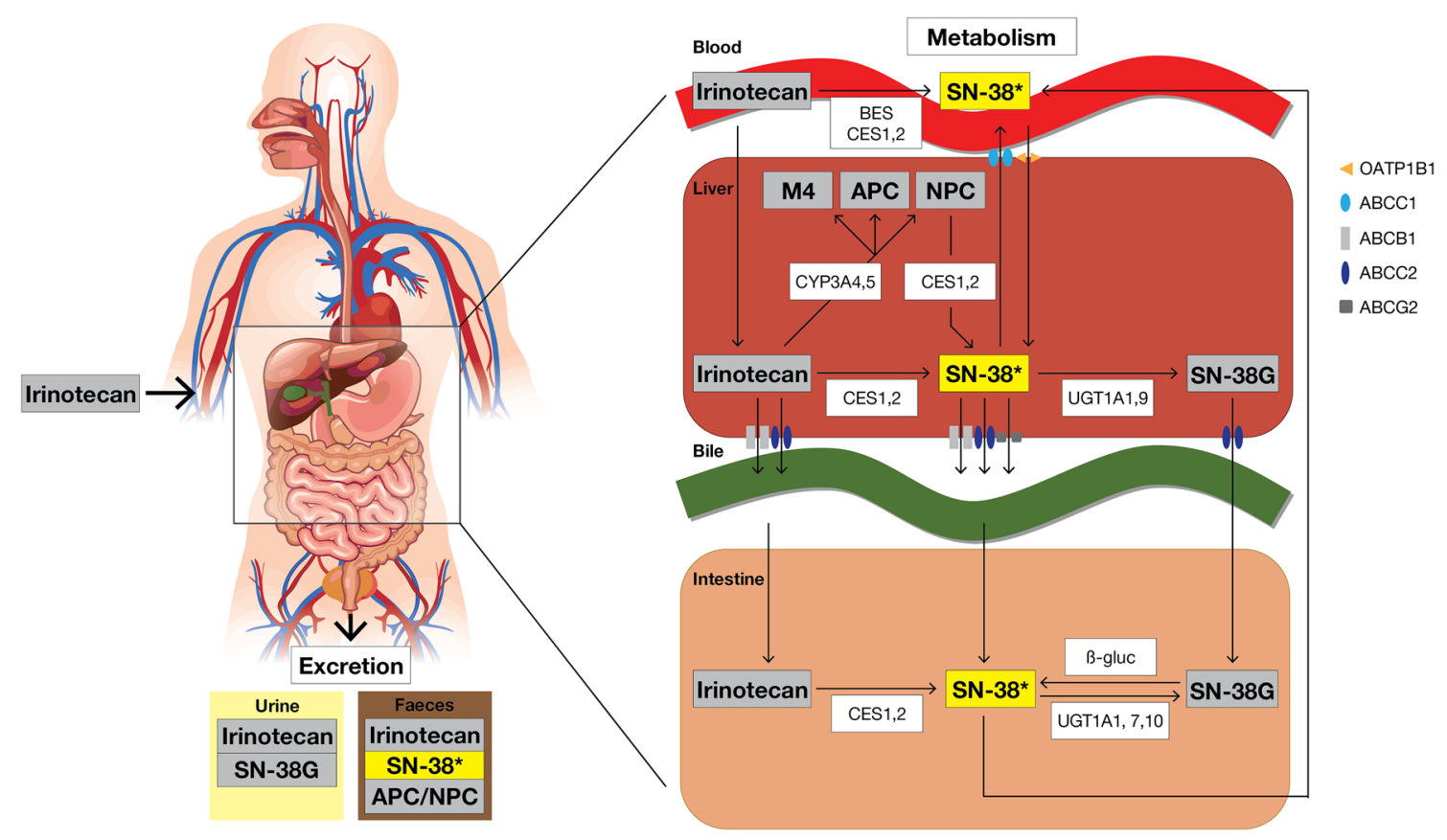

Fig. 2 Irinotecan metabolism and excretion. The main excretion routes of all metabolites are depicted. * Active metabolite. CES carboxylesterase, BES butyrylcholinesterase, CYP cytochrome $\mathrm{P} 450$ enzymes, $U G T$ uridine diphosphate glucuronosyltransferase, $\beta$-gluc $\beta$-glucuronidase 
highly efficient glucuronidation rate of SN-38 into SN-38G [4]. UGT1A1 also conjugates bilirubin, and a significant correlation between SN-38 and bilirubin glucuronidation has been observed [42]. In addition, patients genetically predisposed with decreased UGT1 activity, e.g. in Gilbert's syndrome, are at higher risk for severe toxicity when treated with irinotecan [48]. In addition, many other $U G T$ polymorphisms have been described and their influence on irinotecan pharmacokinetics and pharmacodynamics is summarized in Sect. 4.

\subsubsection{Metabolism by Cytochrome P450 Enzymes}

Irinotecan is also metabolized by intrahepatic cytochrome P450 (CYP) enzymes, i.e. CYP3A4 and CYP3A5, into inactive metabolites-APC and NPC [49]. In contrast to APC, NPC can be converted to SN-38 by CES1 and CES2 in the liver, but to a lesser amount than irinotecan [50]. The importance of CYP3A4 and CYP3A5 in irinotecan metabolism is underlined by the strong correlation between irinotecan and midazolam clearance [51]. Midazolam is an important CYP3A probe drug, and we previously conducted a randomized clinical trial aiming to individualize irinotecan dosing by use of a CYP3A4 phenotype-based algorithm. By dosing on this algorithm, the interindividual variability in irinotecan and SN-38 exposure dramatically reduced compared with conventional dosing [52]. In addition, smoking, some herbal supplements, and comedication are known to induce or inhibit CYP3A enzymes, resulting in interactions with irinotecan, which are summarized in more detail in Sect. 2.5.

\subsubsection{Metabolism by $\beta$-Glucuronidases}

As previously mentioned, SN-38G can be deconjugated into $\mathrm{SN}-38$ by $\beta$-glucuronidases produced by intestinal bacteria, which could result in an enterohepatic circulation of SN-38 [15, 53-55]. In addition, $\beta$-glucuronidase activity has been correlated to intestinal damage and diarrhea in rats/mice, which could (potentially) be reduced by inhibiting $\beta$-glucuronidase with antibiotics (penicillin and streptomycin) or amopaxine [56, 57]. Nonetheless, attempts to reduce $\beta$-glucuronidase activity by neomycin did not significantly alter the irinotecan pharmacokinetic profile in patients [58].

\subsection{Elimination}

The clearance of irinotecan is mainly biliary (66\%) and independent of dose, estimated at $12-21 \mathrm{~L} / \mathrm{h} / \mathrm{m}^{2}[59,60]$. Irinotecan is transported into the bile by several ATPbinding cassette $(\mathrm{ABC})$ transporters (i.e. $\mathrm{ABCB} 1, \mathrm{ABCC} 2$, and ABCG2) [see Fig. 2] [61-63]. In addition, active efflux by $\mathrm{ABCB} 1$ has been shown to lead to low intracerebral irinotecan concentrations in mice [64]. All metabolites, except SN-38G, are predominately excreted in feces, although they are also detectable in urine [4, 59]. Terminal elimination half-lives $\left(t_{1 / 2}\right)$ between 5 and $18 \mathrm{~h}$ for irinotecan, and between 6 and $32 \mathrm{~h}$ for SN-38, were reported [4, 12-14, 59, 65-71]. However, it was later shown that the $\mathrm{t}_{1 / 2}$ was initially underestimated as $\mathrm{SN}-38$ concentrations can be detected up to $500 \mathrm{~h}$ after infusion [72, 73].

The wide interindividual variability in irinotecan clearance is still not completely understood. Primarily, a decreased clearance in patients with altered hepatic function has been described [12, 13]. Additionally, increasing age may negatively influence irinotecan clearance, although this could not be confirmed in another analysis $[13,74]$. Conflicting effects of gender on irinotecan pharmacokinetics have also been proposed. Several studies reported higher irinotecan exposure in women, which, in part, could be explained by decreased SN-38 (metabolic) clearance $[13,59,75]$, while others found no gender effect [4, 74, 76]. Several factors such as dose, timing of administration, enzyme activity, and hematocrit levels might be responsible for these differences. In addition, firm conclusions cannot be drawn for weight [13, 77]. Worse clinical performance has been demonstrated to decrease irinotecan clearance [13]. However, interindividual variability does not seem to be related to body size measures such as body surface area (BSA). Although irinotecan dose is generally based on BSA, it has been shown that BSA and other body size measures do not predict irinotecan pharmacokinetics, and that flat-fixed dosing could be a safe alternative [74, 78].

\subsection{Other Formulations and Administrations}

\subsubsection{Other Formulations}

Furthermore, several other irinotecan formulations have been evaluated. First, oral administration of several different formulations has been investigated and deemed feasible in phase I trials [79-81], but its poor and highly variable bioavailability have limited its current clinical usability [82].

Second, irinotecan drug-eluting beads (DEBIRI) have been developed to control drug release and are mostly used as regional administration. DEBIRI administered into the hepatic artery resulted in higher and prolonged intratumoral irinotecan and SN-38 exposure in liver metastases, whereas systemic exposure was lower than after intravenous administration [83-85]. Hepatic arterial infusion of DEBIRI has been demonstrated to be an effective treatment for unresectable liver metastases [86]. 
Third, liposomal irinotecan has been developed and is clinically used. Encapsulated into liposomes, irinotecan is stable for a longer period of time, resulting in increased accumulation in tumor tissue and thereby increasing its effect, as described further in Sect. 3.2 [87].

\subsubsection{Other Variations in Administration}

Irinotecan administration based on circadian timing improved clinical outcome in several clinical trials [88-90], probably due to the circadian rhythm of enzymes and transporters involved in irinotecan pharmacokinetics and pharmacodynamics [91-93]. However, pharmacokinetic consequences have only been investigated in a small randomized study in which an increased metabolic ratio (SN-38/irinotecan AUC) and smaller interindividual variability were found after circadian-timed dosing [94].

Trials on two different-more regional infusion methods-have been conducted. First, locoregional therapy with irinotecan infusion into the hepatic artery has been evaluated for the treatment of unresectable liver metastases; different irinotecan formulations have been demonstrated to be safe and effective $[95,96]$. This approach resulted in lower systemic exposure to irinotecan and an increased conversion of irinotecan into $\mathrm{SN}-38$ compared with intravenously administered irinotecan [97]. Second, the use of irinotecan as hyperthermic intraperitoneal chemotherapy (HIPEC) has been investigated as a treatment option for colorectal peritoneal metastases [98-103]. A small fraction of irinotecan is rapidly converted intraperitoneally into $\mathrm{SN}$ 38; systemic maximum concentration $\left(C_{\max }\right)$ of $\mathrm{SN}-38$ has been observed $30 \mathrm{~min}$ after intraperitoneal administration [98, 100].

Although these different administration methods have been investigated for several years, there is still insufficient evidence that implementing these strategies in daily care could be beneficial.

\subsection{Drug-Drug Interactions (DDIs)}

\subsubsection{DDIs with Anticancer Drugs}

Many anticancer agents have been investigated in combination with irinotecan, of which no significant pharmacokinetic interactions with irinotecan have been reported for oxaliplatin, 5-fluorouracil/leucovorin, capecitabine, and monoclonal antibodies [66, 70, 104-123]. In contrast, paclitaxel combined with irinotecan in a 3-weekly regimen caused a significant increase in irinotecan, $\mathrm{SN}-38$, and SN$38 \mathrm{G}$ exposure, which was assumed to be caused by competitive inhibition of ABCB1 (Table 1) [124]. Sequencing the administration of paclitaxel after irinotecan seems to improve their synergistic anticancer effects [125], but irinotecan pharmacokinetics are not significantly altered in either sequence $[125,126]$. Systemic SN-38 exposure was found to be reduced in patients concomitantly treated with tegafur (S-1) or carboplatin [127-129], of which the latter also reduced irinotecan exposure. Patients seemed to tolerate irinotecan better when thalidomide was coadministered in two phase II studies in which SN-38G exposure was increased at the expense of SN-38 exposure [130]. However, the pharmacokinetic differences could not be replicated [131, 132] and might be caused by confounding as half of the patients also used antiepileptic drugs (AEDs) [130].

Tyrosine kinase inhibitors (TKIs) have become very popular in cancer treatment but are also known for their modulating effects on drug-metabolizing enzymes [133]. Several TKIs, i.e. imatinib, pazopanib, sunitinib, lapatinib and gefitinib, have been investigated in combination with irinotecan-containing regimens [134-141]. With the exception of pazopanib and lapatinib, all of these combinations led to excessive toxicity and have therefore not been evaluated further for clinical use. Increased exposure to irinotecan or $\mathrm{SN}-38$ due to the inhibition of CYP3A4, $\mathrm{ABCB} 1$, or $\mathrm{ABCG} 2$ has been suggested as a cause of the intolerance of irinotecan combined with TKIs, but a pharmacodynamic interaction cannot be ruled out.

\subsubsection{DDIs with Non-Anticancer Drugs}

Concomitant treatment with non-anticancer drugs such as AEDs, certain antidepressants, antiretroviral drugs, and nonsteroidal anti-inflammatory drugs (NSAIDs) have been shown to affect irinotecan pharmacokinetics or pharmacodynamics. The combination with the potent CYP3A4 inhibitor ketoconazole was one of the first significant DDIs described for irinotecan (Table 1) [142]. Anecdotally, severe rhabdomyolysis syndrome has been described in a patient using irinotecan and citalopram [143]. Although pharmacokinetic data were not available, competitive metabolism by CYP3A4 was suspected as the underlying mechanism. Hypothetically, other strong CYP3A4-inhibiting antidepressants such as nefazodone could be suspected for an interaction with irinotecan [144].

AEDs are also known for inducing CYP3A, UGTs and CES [145]. The influence of phenytoin, phenobarbital, and carbamazepine on irinotecan pharmacokinetics was evaluated in a population pharmacokinetic model, which suggested that patients using these AEDs should receive a 1.7fold higher irinotecan dose to reach the same exposure as in patients without AEDs [75]. Individual patients may require an even higher dose, as indicated by a fourfold higher irinotecan clearance and tenfold lower systemic SN38 exposure in a patient receiving phenytoin [146]. Therefore, the combination of phenytoin and irinotecan 
Table 1 Drug-drug interactions with irinotecan

\begin{tabular}{|c|c|c|c|c|c|c|}
\hline Drug/OTC/lifestyle & $N$ & Enzyme/transporter & Irinotecan dose & \multicolumn{2}{|c|}{ PK alterations } & References \\
\hline \multicolumn{7}{|l|}{ Anticancer drugs } \\
\hline Paclitaxel & 31 & $\mathrm{ABCB} 1$ & $40-60 \mathrm{mg} / \mathrm{m}^{2}$ & Irinotecan & $\mathrm{AUC}_{24.5} 32.7 \% \uparrow$ & [124] \\
\hline $135-200 \mathrm{mg} / \mathrm{m}^{2}$ & & & $\mathrm{D} 1+8, \mathrm{Q} 3 \mathrm{~W}$ & $\mathrm{SN}-38$ & $\mathrm{AUC}_{24.5} 40.4 \% \uparrow$ & \\
\hline D8 & & & & $\mathrm{SN}-38 \mathrm{G}$ & $\mathrm{AUC}_{24.5} 46.2 \% \uparrow$ & \\
\hline Thalidomide $400 \mathrm{mg}$ od (for 14D) & 16 & & $350 \mathrm{mg} / \mathrm{m}^{2}, \mathrm{Q} 3 \mathrm{~W}$ & $\begin{array}{l}\mathrm{SN}-38 \\
\mathrm{SN}-38 \mathrm{G}\end{array}$ & $\begin{array}{l}\mathrm{AUC}_{48} 74 \% \downarrow \\
\mathrm{AUC}_{48} 28 \% \uparrow\end{array}$ & {$[130]^{\mathrm{a}}$} \\
\hline $\begin{array}{l}\text { S-1 (tegafur) } \\
100 / 120 \mathrm{mg} / \mathrm{m}^{2}, 4-7 \mathrm{D}\end{array}$ & 4 & ABCG2 & $\begin{array}{l}100-200 \mathrm{mg} / \mathrm{m}^{2} \\
\text { Q2 W }\end{array}$ & SN-38: & $\mathrm{AUC}_{24} 50 \% \downarrow$ & [128] \\
\hline $\begin{array}{l}\text { Imatinib } 300-600 \mathrm{mg} \text { od } \\
\text { Cisplatin } 30 \mathrm{mg} / \mathrm{m}^{2}\end{array}$ & 6 & $\begin{array}{l}\text { CYP3A4, CYP3A5 } \\
\text { CYP2C9 }\end{array}$ & $\begin{array}{l}65 \mathrm{mg} / \mathrm{m}^{2} \\
\mathrm{D} 1+8, \mathrm{Q} 3 \mathrm{~W}\end{array}$ & Irinotecan & $\begin{array}{l}\mathrm{AUC}_{8} 67 \% \uparrow, \mathrm{CL} \\
36 \% \downarrow\end{array}$ & {$[134]$} \\
\hline \multicolumn{7}{|l|}{$\mathrm{D} 1+8$} \\
\hline $\begin{array}{l}\text { Lapatinib } 1250 \mathrm{mg} / \text { day } \\
\text { Leucovorin } 200 \mathrm{mg} / \mathrm{m}^{2}\end{array}$ & 12 & $\begin{array}{l}\text { CYP3A4 } \\
\text { OATP1B1 }\end{array}$ & $\begin{array}{l}108 \mathrm{mg} / \mathrm{m}^{2} \\
\text { Q2W }\end{array}$ & $\mathrm{SN}-38$ & $\begin{array}{c}\mathrm{AUC}_{24} 41 \% \uparrow \\
\mathrm{C}_{\max } 32 \% \uparrow\end{array}$ & [137] \\
\hline $5-\mathrm{FU} 600 \mathrm{mg} / \mathrm{m}^{2}$ & & $\begin{array}{l}\mathrm{ABCB} 1 \\
\mathrm{ABCG} 2\end{array}$ & & & & \\
\hline \multicolumn{7}{|l|}{ Non-anticancer drugs } \\
\hline Ketoconazole $200 \mathrm{mg}$ od for $2 \mathrm{D}$ & 7 & CYP3A4 & $\begin{array}{l}100 \mathrm{mg} / \mathrm{m}^{2} \text { (with } \\
\text { ketoconazole) } \\
350 \mathrm{mg} / \mathrm{m}^{2} \text { (alone) } \\
\text { Q3W }\end{array}$ & $\begin{array}{l}\mathrm{SN}-38 \\
\mathrm{APC}\end{array}$ & $\begin{array}{l}\mathrm{AUC}_{500} 109 \% \uparrow \\
\mathrm{AUC}_{500} 87 \% \downarrow\end{array}$ & [142] \\
\hline $\begin{array}{l}\text { Lopinavir } 400 \mathrm{mg} / \text { ritonavir } 100 \mathrm{mg} \\
\text { combination drug (Kaletra) bid }\end{array}$ & 8 & $\begin{array}{l}\text { CYP3A4 } \\
\text { UGT1A1 } \\
\text { ABCB1 }\end{array}$ & $\begin{array}{l}150 \mathrm{mg} / \mathrm{m}^{2} \\
\mathrm{D} 1+10, \mathrm{Q} 3 \mathrm{~W}\end{array}$ & $\begin{array}{l}\text { Irinotecan } \\
\mathrm{SN}-38 \\
\mathrm{SN}-38 \mathrm{G} \\
\mathrm{APC}\end{array}$ & $\begin{array}{c}\mathrm{AUC}_{\mathrm{inf}} 89 \% \uparrow, \\
\mathrm{CL} 47 \% \downarrow \\
\mathrm{AUC}_{\text {inf }} 204 \% \uparrow \\
\mathrm{AUC}_{\text {inf }} 94 \% \uparrow \\
\mathrm{AUC}_{\text {inf }} 81 \% \downarrow\end{array}$ & [148] \\
\hline Cyclosporine $5-10 \mathrm{mg} / \mathrm{kg}$ & 43 & $\begin{array}{l}\mathrm{ABCB} 1 \\
\mathrm{ABCC} 2\end{array}$ & $25-75 \mathrm{mg} / \mathrm{m}^{2} \mathrm{Q} 1 \mathrm{~W}$ & $\begin{array}{l}\text { Irinotecan } \\
\mathrm{SN}-38\end{array}$ & $\begin{array}{l}\mathrm{CL} 39-64 \% \downarrow \\
\mathrm{AUC}_{24} \\
23-630 \% \uparrow\end{array}$ & {$[147]$} \\
\hline $\begin{array}{l}\text { Cyclosporine }+ \\
\text { Phenobarbital } 90 \mathrm{mg} \text { for 14D }\end{array}$ & 39 & $\begin{array}{l}\text { ABCB1 } \\
\text { ABCC2 } \\
\text { UGT1A1 }\end{array}$ & $72-144 \mathrm{mg} / \mathrm{m}^{2} \mathrm{Q} 1 \mathrm{~W}$ & $\begin{array}{l}\text { Irinotecan } \\
\mathrm{SN}-38 \\
\mathrm{SN}-38 \mathrm{G}\end{array}$ & $\begin{array}{c}\mathrm{AUC}_{24} 27 \% \downarrow, \\
\mathrm{CL} 43 \% \uparrow \\
\mathrm{AUC}_{24} 75 \% \downarrow \\
\mathrm{AUC}_{24} 50 \% \downarrow\end{array}$ & \\
\hline Celecoxib $400 \mathrm{mg}$ bid & 11 & & $\begin{array}{l}50-60 \mathrm{mg} / \mathrm{m}^{2} \\
\mathrm{D} 1+8, \mathrm{Q} 3 \mathrm{~W}\end{array}$ & $\begin{array}{l}\text { Irinotecan } \\
\mathrm{SN}-38\end{array}$ & $\begin{array}{l}\mathrm{CL} 18 \% \uparrow \\
\mathrm{AUC}_{12.5} 21.8 \% \downarrow\end{array}$ & {$[151]^{\mathrm{a}}$} \\
\hline Methimazole & 14 & UGT1A & $\begin{array}{l}660 \mathrm{mg} \\
\mathrm{Q} 3 \mathrm{~W}\end{array}$ & $\begin{array}{l}\mathrm{SN}-38 \\
\mathrm{SN}-38 \mathrm{G}\end{array}$ & $\begin{array}{l}\mathrm{AUC}_{56} 14 \% \uparrow \\
\mathrm{AUC}_{56} 67 \% \uparrow\end{array}$ & {$[150]$} \\
\hline \multicolumn{7}{|c|}{ Herbal and dietary supplements, and lifestyle } \\
\hline Cigarette smoking & 190 & $\begin{array}{l}\text { CYP3A } \\
\text { UGT1A1 }\end{array}$ & $\begin{array}{l}350 \mathrm{mg} / \mathrm{m}^{2} \text { or } \\
600 \mathrm{mg} \text { fixed dose } \\
\mathrm{Q} 3 \mathrm{~W}\end{array}$ & $\begin{array}{l}\text { Irinotecan } \\
\mathrm{SN}-38\end{array}$ & $\begin{array}{c}\mathrm{AUC}_{100} 15 \% \downarrow, \\
\mathrm{CL} 18 \% \uparrow \\
\mathrm{AUC}_{100} 38 \% \downarrow\end{array}$ & {$[162]$} \\
\hline St. John's wort $300 \mathrm{mg}$ tid & 5 & CYP3A4 & $\begin{array}{l}350 \mathrm{mg} / \mathrm{m}^{2} \\
\text { Q3W }\end{array}$ & SN-38 & $\mathrm{AUC}_{24} 42 \% \downarrow$ & {$[158]$} \\
\hline
\end{tabular}

All PK alterations mentioned are significant at $p<0.05$

$N$ sample size, $D$ day, $o d$ once daily, bid twice daily, tid three times daily, $A U C$ area under the curve, inf infinity, $C L$ clearance, $Q 1 W$ every week, $Q 2 W$ every 2 weeks, $Q 3 W$ every 3 weeks, $P K$ pharmacokinetics, $C Y P$ cytochrome P450, $C_{\text {max }}$ maximum concentration, 5-FU 5-fluorouracil

${ }^{\mathrm{a}}$ For thalidomide and celecoxib, conflicting data have been published between pharmacokinetic drug interactions with irinotecan. Studies that did not show a significant drug-drug interaction $[131,132,152,153]$ are illustrated in more detail in the text 
must be avoided (if possible), or dosing must be guided on irinotecan pharmacokinetics to ensure a sufficient exposure. In addition, Innocenti et al. found a decreased exposure to $\mathrm{SN}-38$ when irinotecan was combined with cyclosporine and the AED phenobarbital (Table 1) [147].

In addition, an important DDI between irinotecan and the combination treatment with ritonavir and lopinavir, caused by CYP3A4, UGT1A1, and ABC transporter inhibition resulted in a more than twofold increase in $\mathrm{SN}-38$ AUC and a $36 \%$ decrease in the SN-38G/SN-38 AUC ratio (Table 1) [148]. A similar effect could be expected of atazanavir, which is also a strong inhibitor of CYP3A4 and UGT1A1 [149]. In contrast, by UGT1A induction by methimazole, an increase in SN-38 and SN-38G concentrations, as well as an almost $50 \%$ increased ratio of SN38G/SN-38, was found by within-patient comparison (Table 1) [150].

With regard to frequently used drugs such as NSAIDs and proton pump inhibitors, only a possible DDI with celecoxib and omeprazole has been evaluated to date. One of three studies investigating the coadministration of irinotecan and celecoxib described an increased clearance of irinotecan and a decreased AUC of SN-38, although the mechanism is not clear (Table 1) [151-153]. Although omeprazole influences UGT, CYP3A, ABCB1, and ABCG2, a clinically relevant pharmacokinetic interaction with irinotecan was ruled out in a small crossover study [154].

\subsubsection{DDIs with Herbal and Dietary Supplements, and Lifestyle}

In general, herbal and dietary supplements are frequently used by cancer patients [155, 156]. Unfortunately, the potential for herb-drug interactions in oncology is not frequently investigated in clinical studies [157]. To date, the effects of St. John's wort (SJW), milk thistle, cigarette smoking, and cannabis tea on irinotecan pharmacokinetics have been investigated. Concomitant use of SJW resulted in a $42 \%$ reduction of $\mathrm{SN}-38$ AUC, primarily caused by CYP3A4 induction (Table 1) [158]. Flavonoids are components of many herbs, such as milk thistle (Silybum marianum), and are able to inhibit CYP3A4, UGT1A1 and $\mathrm{ABC}$ transporters [159-161], but an interaction has not yet been demonstrated in clinical trials [161].

Cigarette smoking resulted in a decrease in irinotecan and SN-38 exposure, possibly caused by CYP3A induction (Table 1) [162]. In addition, (medicinal) cannabis can induce CYP3A4 and inhibit $\mathrm{ABCB} 1$, and its use is becoming more popular in cancer patients. Although no interaction was demonstrated between irinotecan and medicinal cannabis tea [163], other cannabis formulations contain different concentrations of the enzyme-modulating compounds (e.g. cannabidiol and delta-9-tetrahydrocannabinol [THC]). Therefore, it remains unclear if cannabinoid oils, the most popular formulation nowadays, are safe in combination with irinotecan.

\section{Pharmacodynamics}

\subsection{Toxicity}

Irinotecan is known for its dose-limiting adverse events, primarily diarrhea, neutropenia, and asthenia. Of patients with irinotecan monotherapy, $16-31 \%$ experience severe diarrhea, and a comparable percentage of patients suffer from severe neutropenia and severe asthenia, classified as Common Terminology Criteria for Adverse Events (CTCAE) grade 3 or worse [164-168]. Patients treated with a 5-fluorouracil, leucovorin and irinotecan (FOLFIRI) regimen experience severe diarrhea $(9-44 \%)$ and severe neutropenia $(18-54 \%)$ to the same extent [168-173]. In addition, neutropenia appears to occur more frequently in females [174]. Although irinotecan dose is lower in this regimen, 5-fluorouracil could also cause these adverse events.

Two types of diarrhea caused by irinotecan can be distinguished: early- and late-onset diarrhea. Early-onset diarrhea starts during, or immediately after, drug infusion and is caused by increased cholinergic activity, which stimulates intestinal contractility and reduces the absorptive capacity of the mucosa [175]. In addition, early-onset diarrhea is often part of an acute cholinergic syndrome with diaphoresis and abdominal pain. The overall incidence of this syndrome is approximately $70 \%$ without premedication, and is reduced to $9 \%$ by administration of anticholinergic agents (i.e. atropine or hyoscyamine) before irinotecan infusion [176, 177]. Late-onset diarrhea occurs approximately $8-10$ days after irinotecan infusion and is characterized by a more severe course, which is probably caused by damage of the intestinal mucosa due to increased oxidative stress by biliary-secreted or intestinally deconjugated SN-38 [76, 178-180]. Several guidelines recommend treating late-onset diarrhea with loperamide or, alternatively, octreotide [181, 182]. Antibiotics have also been used in clinical practice despite sufficient evidence supporting this strategy [182]; however, these interventions are not always sufficient, which could lead to dose reductions, treatment interruptions and hospitalization.

Conflicting results have been reported regarding the relationship between irinotecan and $\mathrm{SN}-38$ exposure and toxicity (Table 2) [60]. An initial study suggested the biliary index (i.e. the ratio of SN-38 to SN-38G AUCs multiplied by the AUC of irinotecan) as a better predictor for gastrointestinal toxicity [178]. Studies on this subject have 
Table 2 Irinotecan toxicity in relation to pharmacokinetics and biliary index

\begin{tabular}{|c|c|c|c|c|c|c|}
\hline Study, year & $N$ & Irinotecan dose & Irinotecan & $\mathrm{SN}-38$ & SN-38G & Biliary index \\
\hline \multicolumn{7}{|l|}{ Diarrhea } \\
\hline Ohe et al., 1992 [185] & 36 & $\begin{array}{l}5-40 \mathrm{mg} / \mathrm{m}^{2} \\
5 \mathrm{D}, \text { continuously }\end{array}$ & Yes $^{\mathrm{a}}$ & No & $\mathrm{ND}$ & ND \\
\hline de Forni et al., 1994 [186] & 59 & $50-145 \mathrm{mg} / \mathrm{m}^{2} \mathrm{Q} 1 \mathrm{~W}$ & Yes $^{\mathrm{a}}$ & Yes $^{\mathrm{a}}$ & $\mathrm{ND}$ & ND \\
\hline Rowinsky et al., 1994 [65] & 32 & $100-345 \mathrm{mg} / \mathrm{m}^{2} \mathrm{Q} 3 \mathrm{~W}$ & No & No & ND & ND \\
\hline Gupta et al., 1994 [178] & 21 & $100-175 \mathrm{mg} / \mathrm{m}^{2} \mathrm{Q} 1 \mathrm{~W}$ & No & No & No & Yes $^{\mathrm{b}}$ \\
\hline Abigerges et al., 1995 [187] & 64 & $100-750 \mathrm{mg} / \mathrm{m}^{2} \mathrm{Q} 3 \mathrm{~W}$ & Yes $^{\mathrm{c}}$ & Yes $^{\mathrm{c}}$ & ND & ND \\
\hline Catimel et al., 1995 [67] & 46 & $\begin{array}{l}33-115 \mathrm{mg} / \mathrm{m}^{2} \\
\text { D1-D3, Q3W }\end{array}$ & Yes $^{\mathrm{a}}$ & No & $\mathrm{ND}$ & ND \\
\hline Gupta et al., 1997 [76] & 40 & $145 \mathrm{mg} / \mathrm{m}^{2} \mathrm{Q} 1 \mathrm{~W}$ & No & No & No & Yes $^{\mathrm{b}}$ \\
\hline Canal et al., 1996 [68] & 47 & $350 \mathrm{mg} / \mathrm{m}^{2} \mathrm{Q} 3 \mathrm{~W}$ & No & No & No & No \\
\hline Mick et al., 1996 [183] & 36 & $145 \mathrm{mg} / \mathrm{m}^{2} \mathrm{Q} 1 \mathrm{~W}$ & ND & ND & ND & Yes $^{\mathrm{a}}$ \\
\hline Rothenberg et al., 1996 [188] & 48 & $125-150 \mathrm{mg} / \mathrm{m}^{2} \mathrm{Q} 1 \mathrm{~W}$ & No & Yes $^{\mathrm{a}}$ & $\mathrm{ND}$ & ND \\
\hline Herben et al., 1999 [184] & 29 & $10-12.5 \mathrm{mg} / \mathrm{m}^{2} \mathrm{D} 14-21$, continuously & No & No & No & No \\
\hline de Jong et al., 2000 [66] & 52 & $175-300 \mathrm{mg} / \mathrm{m}^{2} \mathrm{Q} 3 \mathrm{~W}$ & No & No & $\mathrm{ND}$ & No \\
\hline Xie et al., 2002 [16] & 109 & $100-350 \mathrm{mg} / \mathrm{m}^{2} \mathrm{Q} 3 \mathrm{~W}$ & Yes $^{1}$ & No & Yes $^{\mathrm{a}}$ & No \\
\hline \multicolumn{7}{|l|}{ Neutropenia } \\
\hline Ohe et al., 1992 [185] & 36 & $\begin{array}{l}5-40 \mathrm{mg} / \mathrm{m}^{2} \\
5 \mathrm{D}, \text { continuously }\end{array}$ & No & Yes $^{\mathrm{d}}$ & ND & ND \\
\hline de Forni et al., 1994 [186] & 59 & $50-145 \mathrm{mg} / \mathrm{m}^{2} \mathrm{Q} 1 \mathrm{~W}$ & $\mathrm{Yes}^{\mathrm{e}}$ & Yes $^{\mathrm{e}}$ & $\mathrm{ND}$ & ND \\
\hline Rowinsky et al., 1994 [65] & 32 & $100-345 \mathrm{mg} / \mathrm{m}^{2} \mathrm{Q} 3 \mathrm{~W}$ & No & Yes $^{\mathrm{e}}$ & ND & ND \\
\hline Abigerges et al., 1995 [187] & 64 & $100-750 \mathrm{mg} / \mathrm{m}^{2} \mathrm{Q} 3 \mathrm{~W}$ & Yes $^{\mathrm{d}}$ & Yes $^{\mathrm{d}}$ & $\mathrm{ND}$ & ND \\
\hline Catimel et al., 1995 [67] & 46 & $\begin{array}{l}33-115 \mathrm{mg} / \mathrm{m}^{2} \\
\text { D1-D3, Q3W }\end{array}$ & No & No & $\mathrm{ND}$ & ND \\
\hline Canal et al., 1996 [68] & 47 & $350 \mathrm{mg} / \mathrm{m}^{2} \mathrm{Q} 3 \mathrm{~W}$ & Yes $^{\mathrm{e}}$ & Yes $^{\mathrm{e}}$ & No & No \\
\hline Rothenberg et al., 1996 [188] & 48 & $125-150 \mathrm{mg} / \mathrm{m}^{2} \mathrm{Q} 1 \mathrm{~W}$ & No & No & ND & ND \\
\hline Herben et al., 1999 [184] & 29 & $10-12.5 \mathrm{mg} / \mathrm{m}^{2} \mathrm{D} 14-21$, continuously & No & No & No & No \\
\hline de Jong et al., 2000 [66] & 52 & $175-300 \mathrm{mg} / \mathrm{m}^{2} \mathrm{Q} 3 \mathrm{~W}$ & No & No & $\mathrm{ND}$ & ND \\
\hline Mathijssen et al., 2002 [73] & 26 & $350 \mathrm{mg} / \mathrm{m}^{2} \mathrm{Q} 3 \mathrm{~W}$ & ND & Yes $^{\mathrm{f}}$ & ND & ND \\
\hline
\end{tabular}

All assumed relationships mentioned are significant at $p<0.05$

$N$ sample size, $N D$ not determined, $D$ day, $Q 1 W$ every week, $Q 3 W$ every 3 weeks

${ }^{a}$ Diarrhea frequency, all grades

${ }^{\mathrm{b}}$ Diarrhea grade $\geq 3$

${ }^{\mathrm{c}}$ Diarrhea $\geq 2$

${ }^{\mathrm{d}}$ Absolute decrease in neutrophil count, all grades

${ }^{\text {e}}$ Percentage decrease in neutrophil count, all grades

${ }^{\mathrm{f}}$ Entire time course of absolute neutrophil count decrease

been contradictory; a higher biliary index was significantly correlated with a higher incidence of severe diarrhea in several studies [76, 178, 183], whereas no significant association was found in other studies (see Table 2) $[16,66,68,184]$. The duration of neutropenia has been found to be significantly correlated to prolonged systemic $\mathrm{SN}-38$ exposure [73].

Several interventions to prevent diarrhea have been investigated, such as reducing the intestinal exposure of
SN-38. First, in a phase I study, SN-38 excretion in the bile was inhibited by combining irinotecan with cyclosporine (due to $\mathrm{ABCC} 2$ and $\mathrm{ABCB} 1$ inhibition). Subsequently, phenobarbital (as a UGT1A1 inductor) was added, and the combination of cyclosporine/phenobarbital/irinotecan resulted in a 75\% reduction of SN-38 AUC [147]. However, when studied in a large, randomized, phase III trial, the combination of cyclosporine, irinotecan and panitumumab did not significantly reduce the incidence of severe 
diarrhea [189]. In another randomized trial, prophylactic use of racecadotril, an antisecretory drug, also failed to reduce this adverse event [190]. Alternatively, SN-38 can be bound to activated charcoal or calcium aluminosilicate clay in the intestine. Until now, only the activated charcoal has been found to reduce the incidence of diarrhea [191, 192]; however, evidence from a phase III study and additional pharmacokinetic analysis is warranted to understand the real effect of activated charcoal, which also exhibits a general antidiarrhoeic effect, and therefore the use of charcoal is not common practice.

Another attempt to reduce toxicity was by inhibition of $\beta$-glucuronidase production by antibiotics (i.e. streptomycin, penicillin, and neomycin), amopaxine, and herbal medicines, all without a relevant reduction in diarrhea incidence [56-58, 193]. However, when combined with cholestyramine to reduce reabsorption, $\beta$-glucuronidase inhibition by levofloxacin was found to reduce irinotecaninduced diarrhea [194]. In addition, a randomized doubleblind, placebo-controlled trial showed a $20 \%$ reduction in diarrhea incidence when irinotecan was combined with probiotics. Unfortunately, this did not result in a significant difference between groups, probably due to a lack of statistical power [195]. Lastly, altering the intestinal environment by alkalinization or reduction of inflammation (by the use of budesonide) did also not reduce intestinal toxicity [196-201].

Currently, fasting before chemotherapy is investigated to reduce toxicity, which has been shown to be effective in mice without affecting the anticancer effects. Systemic and hepatic exposure to $\mathrm{SN}-38$ was reduced in these mice, but intratumoral concentrations were unaltered [202, 203]. A prospective trial is currently ongoing in order to assess the effects of fasting in irinotecan-treated patients and to elucidate the underlying biological mechanisms (http://www. trialregister.nl/; trial ID: NTR5731).

\subsection{Efficacy}

Irinotecan is effective in a wide range of malignancies. In metastatic colorectal cancer (mCRC), irinotecan has its most prominent role as monotherapy or within combination therapy. As first-line mCRC treatment, the FOLFIRI regimen proved to be superior to 5-fluorouracil with leucovorin and to irinotecan monotherapy; a response rate (RR) of $39 \%$ and median overall survival (OS) of 14.8-17.4 months has been reported [168, 169]; however, the addition of oxaliplatin to this regimen (i.e. FOLFOXIRI) substantially increased treatment efficacy, as shown by an RR of $60 \%$ and median OS of approximately 23 months [204, 205]. As second-line treatment after 5-fluorouracilcontaining regimens, irinotecan leads to a significantly longer OS than 5-fluorouracil with leucovorin or best supportive care (BSC) [166, 167]. For patients with a KRAS wild-type tumor, efficacy of palliative treatment could be increased by combining irinotecan monotherapy, FOLFIRI, or FOLFOXIRI with monoclonal antibodies (e.g. bevacizumab, cetuximab, panitumumab, ramucirumab) $[165,170-172,206,207]$. In the adjuvant setting, the addition of irinotecan to 5-fluorouracil and leucovorin did not result in a survival benefit $[208,209]$. Patients with tumors characterized by high microsatellite instability (MSI) have been suggested to respond better to irinotecanbased chemotherapy, $[210,211]$ but a recent meta-analysis failed to show any predictive value of MSI status in relation to treatment response [212].

For advanced esophageal or junction tumors, irinotecan has proven to be effective as monotherapy and when combined with cisplatin, mitomycin, capecitabine and oxaliplatin, 5-fluorouracil and leucovorin and docetaxel [213-219]; however, of these regimens, only irinotecan combined with 5-fluorouracil was evaluated in a phase III trial in which this combination was inferior to cisplatin/5fluorouracil [220]. In advanced human epidermal growth factor receptor 2 (HER2)-negative gastric cancer, the addition of irinotecan to different combination therapies gave an OS benefit in a pooled analysis of ten studiesmedian OS was 11.3 months and RR was approximately $38 \%$ [221].

Irinotecan is also used in the treatment of small cell lung cancer (SCLC) and non-SCLC (NSCLC). For advanced NSCLC, irinotecan combined with taxanes, platinum, ifosfamide, or gemcitabine demonstrated efficacy as firstline treatment in several trials [222]. For advanced SCLC, irinotecan combined with cisplatin or carboplatin had similar RR and median OS as platinum compounds with etoposide (RR 39-84\% and median OS 9-13 months) and is therefore used as first-line treatment in Japan, whereas the etoposide-containing regimen is preferred elsewhere [223]. Furthermore, irinotecan has demonstrated anticancer activity in phase II trials in a wide range of other solid tumors (i.e. mesothelioma, glioblastoma, gynecological cancers, and head and neck cancer), although no phase III data are available [224-231].

Finally, in pancreatic cancer, the combination of 5-fluorouracil, leucovorin, irinotecan and oxaliplatin (FOLFIRINOX) is used for both first-line adjuvant and palliative treatment in which it was shown to be superior to gemcitabine monotherapy (median OS 11.1 months, RR 31.6\%) [232]. Liposomal irinotecan has recently been approved as second-line treatment for metastatic pancreatic cancer for patients with progression on gemcitabine-based therapies [87]. Efficacy of this liposomal formulation needs to be explored further in other tumor types. 


\section{Pharmacogenetics}

Expression and functionality of enzymes and drug transporters involved in the metabolism and elimination of irinotecan can be affected by genetic polymorphisms that could influence both irinotecan pharmacokinetics and pharmacodynamics. This section provides an overview of clinical correlations between polymorphisms and irinotecan pharmacokinetics and pharmacodynamics.

\subsection{Associations between UGT1A1 Polymorphisms and Irinotecan Pharmacodynamics}

With more than 100 reported genetic variants [233], UGT1A1 is a highly polymorphic enzyme. The most frequently studied UGTIAl polymorphisms in relation to irinotecan pharmacokinetics and pharmacodynamics are $U G T I A 1 * 6$ and $U G T I A 1 * 28$. The majority of the genetic association studies have focused on neutropenia and diarrhea as clinical endpoints [169].

Wild-type UGTIAI is characterized by six thymine adenine (TA) repeats in the promotor region, whereas UGT1Al $* 28$ (rs8175347) carriers have an extra TA repeat that impairs UGTIAl transcription and thereby reduces expression by approximately $70 \%$ [234]. The incidence of this genetic variant is relatively high among Caucasians (minor allele frequency [MAF] 26-39\%) and Africans/ African Americans (MAF 30-56\%) [235, 236]. Among the Asian population, UGTIAl $* 28$ is far less common, as indicated by an MAF of 9-20\% [235, 236]. With a reported MAF of up to $47 \%$, another polymorphism-UGTIAl*6 ( $r s 4148323,211 \mathrm{G}>\mathrm{A})$ - is more common in Asian populations and may therefore be a better predictor for irinotecan-related toxicities in that area of the world [237]. $U G T 1 A 1 * 6$ also results in an approximately $70 \%$ reduction of UGT1A1 activity in individuals carrying the UGT1A1 $* 6 / * 6$ genotype [238].

Both $U G T 1 A 1 * 6$ and $* 28$ polymorphisms result in an increased systemic exposure to irinotecan and SN-38 in patients homozygous for these variants, thereby increasing the risk of irinotecan-associated adverse events [239, 240]. This is also accompanied by increased financial costs of toxicity management [241]. Due to the high number of genetic association studies on the clinical effects of UGTIAI $* 6$ and $* 28$ on irinotecan pharmacokinetics/pharmacodynamics and large differences between studies in terms of tumor type, dosing regimen, and genetic models, this review will mainly focus on meta-analyses for UGTIA $1 * 28$ and $* 6$ to extract the most relevant information with the highest level of evidence (Table 3).

Initially, significant associations between $U G T 1 A 1 * 28$ and hematologic toxicities were only reported for irinotecan doses higher than $180 \mathrm{mg} / \mathrm{m}^{2}$ [242]. However, more recent meta-analyses did not show a dose-dependent effect of $U G T 1 A 1 * 28$. In addition, $* 28$ carriers receiving lower irinotecan doses were at risk of neutropenia [243, 244]. These meta-analyses were carried out in a predominantly Caucasian population, thus regardless of scheduled starting dose, genotyping for UGTIAI*28 and dose reductions in all Caucasian patients homozygous for $U G T 1 A 1 * 28$ may be considered to reduce the risk of severe neutropenia.

Presumably due to the lower incidence of UGTIAI $* 28$ in the Asian population, the effects of $U G T 1 A 1 * 28$ on toxicity endpoints are less straightforward in this population. Several meta-analyses in Asian patients with different tumor types and treatment schedules did not show any significant association between $U G T 1 A 1 * 28$ and irinotecan-induced neutropenia [245, 246]. In contrast, $U G T I A{ }^{*} 6$ seems to be a more accurate predictor of irinotecan-induced toxicity; Asian patients with gastrointestinal tumors or NSCLC were more likely to suffer from neutropenia if they were carrying at least one $U G T 1 A I^{*} 6$ allele (Table 3) [245, 247]. This association does not seem to be dose-dependent [248].

Both Caucasian and Asian patients homozygous or heterozygous for $U G T 1 A 1 * 28$ have a greater risk of suffering from severe diarrhea compared with wild-type patients after receiving irinotecan doses $>125 \mathrm{mg} / \mathrm{m}^{2}$ [249]. In another meta-analysis among Caucasian $* 28 / * 28$ carriers, this dose-dependent effect was also observed [244]. In Asian patients, UGTIAI*6 not only correlates well with the risk for irinotecan-induced neutropenia but is also significantly associated with severe diarrhea $[245,248]$. Whether this association is dose-dependent is currently unknown since no dose subgroup analysis has been carried out [250].

It seems that response or survival endpoints are not significantly affected by UGTIAI*6 or $* 28$. Both $U G T 1 A 1 * 6$ and $U G T 1 A 1 * 28$ genotypes did not have any significant association with tumor response in Asian NSCLC or SCLC patients receiving irinotecan as first- or second-line chemotherapy [245]. Furthermore, the presence of one or more $U G T 1 A 1 * 28$ alleles in Caucasian patients with colorectal cancer did not significantly affect overall and progression-free survival (PFS) [251].

Besides $U G T 1 A 1 * 6$ and $U G T 1 A 1 * 28$, other common UGTIA1 polymorphisms could theoretically also affect irinotecan-related toxicity (Table 3 ). For instance, UGTIAI*60 (rs4124874; 3279T $>\mathrm{G})$ is in linkage with $U G T 1 A 1 * 28$ and is associated with a decrease in transcriptional activity [238]. This genetic variant is common among Caucasians (MAF 47\%) and African Americans (MAF 85\%) [252]. Two clinical studies did not report any significant associations between $U G T 1 A 1 * 60$ status and 
Table 3 Overview of pharmacogenetic studies on irinotecan toxicity and survival

\begin{tabular}{|c|c|c|c|c|c|c|c|}
\hline Polymorphism & Ethnicity & Endpoint & $\begin{array}{l}\text { Dose range } \\
\left(\mathrm{mg} / \mathrm{m}^{2}\right)\end{array}$ & Main findings & $\begin{array}{l}\text { No. of } \\
\text { patients }\end{array}$ & $\begin{array}{l}\text { No. of } \\
\text { studies }\end{array}$ & References \\
\hline \multicolumn{8}{|l|}{ Meta-analyses } \\
\hline \multirow{3}{*}{$\begin{array}{l}U G T 1 A 1 * 28 / * 28 \\
(\mathrm{rs} 8175347) \text { vs. } \\
* 1 / * 28 \text { or } * 1 / * 1\end{array}$} & \multirow[t]{3}{*}{ Not reported } & \multirow[t]{3}{*}{$\begin{array}{l}\text { Hematologic } \\
\text { toxicities }\end{array}$} & $80-125$ & $\begin{array}{l}\text { OR } 1.80,95 \% \text { CI } \\
0.37-8.84, p=0.41\end{array}$ & 229 & 3 & \multirow[t]{3}{*}{ [242] } \\
\hline & & & 180 & $\begin{array}{l}\text { OR 3.22, 95\% CI } \\
1.52-6.81, p=0.008\end{array}$ & 410 & 4 & \\
\hline & & & $200-350$ & $\begin{array}{l}\text { OR } 27.8,95 \% \text { CI } 4.0-195 \\
p=0.005\end{array}$ & 184 & 3 & \\
\hline \multirow[t]{3}{*}{$* 28 / * 28$ vs. $* 1 / * 1$} & \multirow[t]{3}{*}{ Mainly Caucasian } & \multirow[t]{3}{*}{ Neutropenia } & $<150$ & $\begin{array}{l}\text { OR } 2.43,95 \% \text { CI } \\
1.34-4.39, p=0.003\end{array}$ & 300 & 4 & \multirow[t]{3}{*}{ [243] } \\
\hline & & & $150-250$ & $\begin{array}{l}\text { OR 2.00, 95\% CI } \\
1.62-2.47, p<0.001\end{array}$ & 1481 & 9 & \\
\hline & & & $\geq 250$ & $\begin{array}{l}\text { OR 7.22, 95\% CI } \\
3.10-16.78, p<0.001\end{array}$ & 217 & 3 & \\
\hline $\begin{array}{l}* 28 / * 28 \text { vs. } * 1 / * 28 \\
\quad \text { or } * 1 / * 1\end{array}$ & Caucasian & Neutropenia & $80-350$ & $\begin{array}{l}\text { OR } 3.44,95 \% \text { CI } \\
2.45-4.82, p<0.00001\end{array}$ & 2015 & 14 & [244] \\
\hline \multirow[t]{2}{*}{$\begin{array}{l}* 28 / * 28 \text { vs. } * 1 / * 28 \\
\text { or } * 1 / * 1\end{array}$} & & Diarrhea & $>150$ & $\begin{array}{l}\text { OR 2.04, 95\% CI } \\
1.23-3.38, p=0.006\end{array}$ & 1317 & 8 & \\
\hline & & & $<150$ & $\begin{array}{l}\text { OR } 1.41,95 \% \text { CI } \\
0.82-2.43, p=0.21\end{array}$ & 663 & 6 & \\
\hline $\begin{array}{l}* 1 / * 28 \text { or } * 28 / * 28 \\
\text { vs. } * 1 / * 1\end{array}$ & \multirow[t]{4}{*}{ Asian } & Neutropenia & $50-100$ & $\begin{array}{l}\text { OR } 1.47,95 \% \text { CI } \\
0.90-2.42, p=0.13\end{array}$ & 515 & 8 & \multirow[t]{4}{*}[245]{} \\
\hline $\begin{array}{l}* 6 / * 6(r s 4148323) \\
\quad \text { vs. } * 1 / * 6 \text { or } * 1 / \\
\quad * 1\end{array}$ & & Diarrhea & & $\begin{array}{l}\text { OR 4.90, 95\% CI } \\
2.02-11.88, p=0.0004\end{array}$ & 225 & 4 & \\
\hline $\begin{array}{l}* 6 / * 6 \text { vs. } * 1 / * 6 \text { or } \\
\quad * 1 / * 1\end{array}$ & & $\begin{array}{l}\text { Tumor } \\
\text { response }\end{array}$ & & $\begin{array}{l}\text { OR } 1.51,95 \% \text { CI } \\
0.78-2.92, p=0.22\end{array}$ & 225 & 4 & \\
\hline $\begin{array}{l}* 28 / * 28 \text { or } * 1 / * 28 \\
\text { vs. } * 1 / * 1\end{array}$ & & & & $\begin{array}{l}\text { OR } 1.03,95 \% \text { CI } \\
0.59-1.82, p=0.91\end{array}$ & 390 & 7 & \\
\hline$* 28 / * 28$ vs. & \multirow[t]{2}{*}{ Asian } & \multirow[t]{2}{*}{ Neutropenia } & $60-200$ & OR $1.67,95 \%$ CI $0.94-2.97$ & 658 & 6 & \multirow[t]{2}{*}{ [246] } \\
\hline$* 6 / * 28$ & & & $30-350$ & $\begin{array}{l}\text { OR } 2.55,95 \% \text { CI } \\
1.82-3.58\end{array}$ & 886 & 13 & \\
\hline $\begin{array}{l}* 6 / * 6 \text { or } * 28 / * 28 \\
\text { or } * 6 / * 28 \text { vs. } * 1 / \\
* 6 \text { or } * 1 / * 28 \text { or } \\
* 1 / * 1\end{array}$ & \multirow[t]{2}{*}{ Asian } & \multirow[t]{2}{*}{ Neutropenia } & \multirow[t]{2}{*}{$60-350$} & $\begin{array}{l}\text { OR 3.275, 95\% CI } \\
2.152-4.983, p=0.000\end{array}$ & 923 & 11 & \multirow[t]{2}{*}[247]{} \\
\hline $\begin{array}{l}* 1 / * 6 \text { or } * 6 / * 6 \text { vs. } \\
\quad * 1 / * 1\end{array}$ & & & & $\begin{array}{l}\text { OR 1.542, 95\% CI } \\
1.180-2.041, p=0.001\end{array}$ & 994 & 9 & \\
\hline$* 6 / * 6$ vs. $* 1 / * 1$ & Asian & Neutropenia & $30-375$ & $\begin{array}{l}\text { OR } 4.44,95 \% \text { CI } \\
2.42-8.14, p<0.001\end{array}$ & 833 & 7 & [248] \\
\hline $\begin{array}{l}* 28 / * 28 \text { or } * 1 / * 28 \\
\text { vs. } * 1 / * 1\end{array}$ & Asian & Diarrhea & $>125$ & $\begin{array}{l}\text { OR 3.02, 95\% CI } \\
1.42-6.44, p=0.004\end{array}$ & 309 & 4 & [249] \\
\hline $\begin{array}{l}* 28 / * 28 \text { or } * 1 / * 28 \\
\text { vs. } * 1 / * 1\end{array}$ & Caucasian & & & $\begin{array}{l}\text { OR } 1.93,95 \% \text { CI } \\
1.38-2.70, p<0.001\end{array}$ & 1096 & 11 & \\
\hline $\begin{array}{l}* 28 / * 28 \text { vs. } * 1 / * 1 \\
* 1 / * 28 \text { vs. } * 1 / * 1\end{array}$ & Caucasian & OS and PFS & $60-350$ & $\begin{array}{l}\text { All comparisons not } \\
\text { significant for both OS } \\
\text { and PFS }(p>0.05)\end{array}$ & $\begin{array}{l}1524(\mathrm{OS}) \\
1494(\mathrm{PFS})\end{array}$ & 10 & [251] \\
\hline Clinical studies & & & & & & & \\
\hline
\end{tabular}


Table 3 continued

\begin{tabular}{|c|c|c|c|c|c|c|c|}
\hline Polymorphism & Ethnicity & Endpoint & $\begin{array}{l}\text { Dose range } \\
\left(\mathrm{mg} / \mathrm{m}^{2}\right)\end{array}$ & Main findings & $\begin{array}{l}\text { No. of } \\
\text { patients }\end{array}$ & $\begin{array}{l}\text { No. of } \\
\text { studies }\end{array}$ & References \\
\hline$U G T 1 A 1 * 60$ & Asian & $\begin{array}{l}\text { PK, tumor } \\
\text { response, } \\
\text { grade } 4 \\
\text { neutropenia, } \\
\text { grade } 3 \\
\text { diarrhea, } \\
\text { delivered } \\
\text { dose }\end{array}$ & 80 & $p>0.05$ for all endpoints & 81 & 1 & {$[253]$} \\
\hline$U G T 1 A 1 * 60$ & $\begin{array}{l}\text { Not specified } \\
\text { (probably } \\
\text { Korean) }\end{array}$ & $\begin{array}{l}\text { Neutropenia, } \\
\text { anorexia, } \\
\text { vomiting, } \\
\text { diarrhea, } \\
\text { abdominal } \\
\text { pain }\end{array}$ & 150 & $p>0.05$ for all endpoints & 42 & 1 & [254] \\
\hline $\begin{array}{l}U G T 1 A 1 * 28, * 60, \\
\quad * 93 \\
(\mathrm{rs} 10929302)\end{array}$ & $\begin{array}{l}\text { Caucasian (50 pts), } \\
\text { Black (10 pts), } \\
\text { Hispanic (4 pts), } \\
\text { Pacific Islander } \\
(1 \mathrm{pt}), \text { Asian (1 } \\
\text { pt) }\end{array}$ & Neutropenia & 350 & $\begin{array}{l}\text { UGT1A1 haplotype }(* 28 / \\
* 60 / * 93) \text { associated with } \\
\text { grade } 4 \text { neutropenia, } \\
p<0.001\end{array}$ & 66 & 1 & [255] \\
\hline $\begin{array}{l}U G T 1 A 1 * 28, * 93, \\
A B C B 1 \\
(\mathrm{rs} 1045642)\end{array}$ & $\begin{array}{l}\text { Not specified, } \\
\text { presumably } \\
\text { Caucasian } \\
\text { (France) }\end{array}$ & $\begin{array}{l}\text { Hematologic } \\
\text { toxicities }\end{array}$ & 180 & $\begin{array}{l}U G T 1 A 1 * 28 / * 28 \text { and } * 93 / \\
* 93: \text { increased risk of } \\
\text { hematologic toxicity } \\
(p=0.01)\end{array}$ & 184 & 1 & {$[258]$} \\
\hline $\begin{array}{l}U G T 1 A 1 * 93, \\
A B C B 1 \\
\text { (rs12720066), } \\
A B C C 1 \\
\text { (rs6498588, } \\
\text { rs17501331) }\end{array}$ & $\begin{array}{l}\text { Caucasian (67 pts), } \\
\text { African } \\
\text { American (11 } \\
\text { pts) }\end{array}$ & $\begin{array}{l}\text { ANC nadir, } \\
\text { SN-38 AUC }\end{array}$ & 300 or 350 & $\begin{array}{c}\text { Increased SN-38 AUC: } \\
U G T 1 A 1 * 93, A B C C 1 \\
(\text { rs6498588) } \\
\text { Decreased SN-38 AUC: } \\
A B C B 1 \text { (rs12720066) } \\
\text { Increased ANC nadir: } \\
A B C B 1 \text { (rs12720066) } \\
\text { Decreased ANC nadir: } \\
U G T 1 A 1 * 93, A B C C 1 \\
(\text { rs17501331) }\end{array}$ & 78 & 1 & {$[256]$} \\
\hline \multirow[t]{2}{*}{$\begin{array}{l}U G T 1 A 1 * 28 \text { and } \\
* 93\end{array}$} & \multirow[t]{2}{*}{$\begin{array}{l}\text { Caucasian (94 pts), } \\
\text { Asian (2 pts) }\end{array}$} & Diarrhea & \multirow[t]{2}{*}{$\begin{array}{l}40-80,180 \\
350\end{array}$} & $\begin{array}{l}U G T 1 A 1 * 28 / * 28 \text { and } * 93 / \\
* 93 \text { associated with } \\
\text { grade } 3 / 4 \text { diarrhea } \\
(p<0.05)\end{array}$ & \multirow[t]{2}{*}{96} & \multirow[t]{2}{*}{1} & \multirow[t]{2}{*}{ [260] } \\
\hline & & Neutropenia & & $\begin{array}{l}\text { No significant effect on } \\
\text { neutropenia }\end{array}$ & & & \\
\hline $\begin{array}{l}U G T 1 A 1: * 28, * 93 \\
U G T 1 A 6: \\
\text { rs2070959 } \\
U G T 1 A 9: * 22 \\
\text { (rs45625337), - } \\
\text { 688A/C variant } \\
U G T 1 A 7 * 3 \\
3^{\prime} U T R: \\
440 C>G \text { variant }\end{array}$ & $\begin{array}{l}\text { Not specified, } \\
\text { presumably } \\
\text { Caucasian } \\
\text { (Canada) }\end{array}$ & Neutropenia & 180 & $\begin{array}{l}U G T 1 A 1 * 93 \text { associated } \\
\text { with neutropenia. } \\
\text { Haplotype (UGT1A1*28, } \\
* 60, * 93, U G T 1 A 7 * 3 \text {, } \\
U G T 1 A 9 * 1) \text { associated } \\
\text { with grade 3-4 } \\
\text { neutropenia: OR } 2.43 \text {, } \\
95 \% \text { CI 1.35-4.39, } \\
p=0.004 \\
\text { Haplotypes 'II' and 'III' } \\
\text { (variants in } U G T 1 A 9, \\
1 A 7,1 A 6, \text { and } 3 \text { ' } U T R \\
\text { wild-type) associated } \\
\text { with grade 3-4 } \\
\text { neutropenia: OR } 2.15 \\
\text { and 5.28, respectively }\end{array}$ & 167 & 1 & [259] \\
\hline
\end{tabular}


Table 3 continued

\begin{tabular}{|c|c|c|c|c|c|c|c|}
\hline Polymorphism & Ethnicity & Endpoint & $\begin{array}{l}\text { Dose range } \\
\left(\mathrm{mg} / \mathrm{m}^{2}\right)\end{array}$ & Main findings & $\begin{array}{l}\text { No. of } \\
\text { patients }\end{array}$ & $\begin{array}{l}\text { No. of } \\
\text { studies }\end{array}$ & References \\
\hline $\begin{array}{l}\text { Among other } \\
\text { genes: } \\
U G T 1 A 1 * 28 \text {, } \\
* 93\end{array}$ & $\begin{array}{l}\text { Caucasian (450 } \\
\text { pts), African } \\
\text { American ( } 36 \\
\text { pts), Hispanic (16 } \\
\text { pts), Asian (9 } \\
\text { pts), other (9 pts) }\end{array}$ & $\begin{array}{l}\text { (Febrile) } \\
\text { neutropenia, } \\
\text { vomiting }\end{array}$ & 125 or 200 & $\begin{array}{l}U G T 1 A I * 93 \text { associated } \\
\text { with grade } 3 \text { febrile } \\
\text { neutropenia, grade } 4 \\
\text { neutropenia }(p<0.001) \\
\text { and grade } 3 \text { vomiting } \\
(p=0.004)\end{array}$ & 520 & 1 & [261] \\
\hline $\begin{array}{l}U G T 1 A 1: * 6, * 28 \\
U G T 1 A 7 * 3 \\
U G T 1 A 9 * 1\end{array}$ & Asian & $\begin{array}{l}\text { Adverse } \\
\text { events, } \\
\text { therapeutic } \\
\text { intervention }\end{array}$ & $\begin{array}{l}60,70,100 \\
\text { or } 180\end{array}$ & $\begin{array}{l}U G T 1 A 1 * 6 / * 28, \\
U G T 1 A 7 * 3 / * 3 \text { or } \\
U G T 1 A 9 * 1 / * 1 \text { : greater } \\
\text { risk of adverse events } \\
\text { and therapeutic } \\
\text { intervention: OR } 11.00, \\
95 \% \text { CI } 1.633-74.083, \\
p=0.014\end{array}$ & 45 & 1 & [263] \\
\hline $\begin{array}{l}U G T 1 A 1 * 28, \\
U G T 1 A 1 * 60, \\
U G T 1 A 1 * 93, \\
U G T 1 A 7 * 3, \text { and } \\
U G T 1 A 9 * 22\end{array}$ & Caucasian & $\begin{array}{l}\text { Hematologic } \\
\text { toxicity, } \\
\text { response rate }\end{array}$ & 180 & $\begin{array}{l}\text { Haplotype II (all variants } \\
\text { except } U G T 1 A 1 * 22) \\
\text { associated with } \\
\text { increased response rate: } \\
\text { OR } 8.61,95 \% \text { CI } \\
1.75-42.38, p=0.01\end{array}$ & 250 & 1 & [262] \\
\hline $\begin{array}{l}\text { Among other } \\
\text { genes: } \\
\text { SLCO1B1 } \\
(r s 4149056)\end{array}$ & Asian & Neutropenia & 65 or 80 & $\begin{array}{l}S L C O 1 B 1 \text { and } \\
U G T 1 A 1 * 6: \text { increased } \\
\text { risk for grade } 4 \\
\text { neutropenia }\end{array}$ & 107 & 1 & [264] \\
\hline $\begin{array}{l}U G T 1 A 1 * 6 \\
U G T 1 A 9 * 22 \\
A B C C 2 \\
(r s 3740066)\end{array}$ & & Diarrhea & & $\begin{array}{l}U G T 1 A 9 * 1 / * 1, \\
A B C C 2(\operatorname{rs3740066)}, \\
A B C G 2(\operatorname{rs} 2231137): \\
\text { increased risk for grade } \\
3 \text { diarrhea }\end{array}$ & & & \\
\hline $\begin{array}{l}A B C G 2 \\
\quad(r s 2231137)\end{array}$ & & & & & & & \\
\hline $\begin{array}{l}\text { Among other } \\
\text { genes: } \\
\text { UGT1A1*93, }\end{array}$ & $\begin{array}{l}\text { African American } \\
(11 \mathrm{pts}) \\
\text { Caucasian }(67\end{array}$ & ANC nadir & 300,350 & $\begin{array}{l}\text { UGT1A1*93, ABCCI } \\
\text { (rs3765129): decreased } \\
\text { ANC nadir }\end{array}$ & 85 & 1 & {$[174]$} \\
\hline $\begin{array}{l}A B C C 1 \\
\quad(r s 3765129), \\
\quad S L C O 1 B 1^{*} 1 b \\
(r s 2306283)\end{array}$ & pts), other (7 pts) & & & $\begin{array}{l}\mathrm{S} L C O 1 B 1 * 1 b(r s 2306283): \\
\text { increased ANC nadir } \\
(p<0.05)\end{array}$ & & & \\
\hline \multirow{2}{*}{$\begin{array}{l}\text { Among other } \\
\text { genes: } A B C B 1 \\
\text { (rs } 1045642, \\
\text { rs1128503, } \\
\text { rs2032582), }\end{array}$} & Caucasian & Toxicity & 180 & $\begin{array}{l}A B C B 1(\text { rs1045642) } \\
\text { associated with early } \\
\text { toxicity: OR } 3.7995 \% \\
\text { CI } 1.09-13.2\end{array}$ & 140 & 1 & {$[268]$} \\
\hline & & Response rate & & $\begin{array}{l}A B C B 1 \text { haplotype } \\
(r s 1045642, \text { rs1128503, } \\
\text { rs2032582): shorter OS, } \\
\text { OR 1.56, 95\% CI } \\
1.01-2.45\end{array}$ & & & \\
\hline $\begin{array}{l}A B C C 2: \\
\text { rs1885301, } \\
\text { rs2804402, } \\
\text { rs717620, } \\
\text { rs2273697, } \\
\text { rs17216177, } \\
\text { rs3740066 }\end{array}$ & Caucasian & Diarrhea & $260-875 \mathrm{mg}$ & $\begin{array}{l}\text { Decreased incidence of } \\
\text { diarrhea for } A B C C 2 * 2 \\
\text { haplotype (rs1885301, } \\
\text { rs2804402, rs717620, } \\
\text { rs2273697, rs17216177, } \\
\text { rs3740066) without } \\
U G T 1 A 1 * 28 \text { allele: OR } \\
0.15,95 \% \text { CI } 0.04-0.61) \\
p=0.005\end{array}$ & 167 & 1 & [271] \\
\hline
\end{tabular}


Table 3 continued

\begin{tabular}{|c|c|c|c|c|c|c|c|}
\hline Polymorphism & Ethnicity & Endpoint & $\begin{array}{l}\text { Dose range } \\
\left(\mathrm{mg} / \mathrm{m}^{2}\right)\end{array}$ & Main findings & $\begin{array}{l}\text { No. of } \\
\text { patients }\end{array}$ & $\begin{array}{l}\text { No. of } \\
\text { studies }\end{array}$ & References \\
\hline $\begin{array}{l}\text { Among other } \\
\text { genes: } A B C C 5 \\
\text { (rs10937158, } \\
\text { rs } 3749438, \\
\text { rs2292997) } \\
A B C G l(r s 225440)\end{array}$ & Caucasian & Diarrhea & 180 & $\begin{array}{l}\text { Reduced risk of diarrhea } \\
\text { for } A B C C 5 \text { haplotype } \\
\text { (rs10937158 and } \\
\text { rs3749438): } \\
\text { OR } 0.39,95 \% \text { CI } \\
0.23-0.67, p=0.0006\end{array}$ & 167 & 1 & {$[272]$} \\
\hline$A B C G 1(\operatorname{rs} 225440)$ & & Neutropenia & & $\begin{array}{l}0.23-0.67, p=0.0006 \\
\text { Increased risk of } \\
\text { neutropenia for co- } \\
\text { occurrence of } A B C G 1 \\
\text { and } A B C C 5 \\
\text { (rs2292997): OR } 5.93 \\
95 \% \text { CI } 2.25-15.59 \\
p=0.0002\end{array}$ & & & \\
\hline$S L C O 1 B 1 * 1 b$ & Caucasian & Neutropenia & $\begin{array}{l}300,350, \\
380-600 \\
(\mathrm{mg})\end{array}$ & $\begin{array}{l}S L C O 1 B 1 * 1 b: \text { increased } \\
\text { ANC nadir }(p<0.05)\end{array}$ & $\begin{array}{l}67 \text { (discovery } \\
\text { cohort), } 108 \\
\text { (replication } \\
\text { cohort) }\end{array}$ & 1 & [273] \\
\hline $\begin{array}{l}\text { Among other } \\
\text { genes: } \\
\text { SLCO1B } 1 * 1 b \text {, } \\
S L C O 1 B 1 * 5 \\
\text { (rs4149056) }\end{array}$ & Caucasian & $\begin{array}{l}\text { SN-38 PK, } \\
\text { toxicity, PFS }\end{array}$ & 180 & $\begin{array}{l}S L C O 1 B 1 * 1 b: \text { increased } \\
\text { PFS }(p<0.05) \text {. } \\
S L C O 1 B 1 * 5: \text { increased } \\
\text { SN-38 plasma } \\
\text { concentration and } \\
\text { increased risk of } \\
\text { neutropenia }(\text { combined } \\
\text { with } U G T 1 A 1 * 28) \\
(p<0.05)\end{array}$ & 127 & 1 & [274] \\
\hline
\end{tabular}

Significant findings are shown in bold

$C I$ confidence interval, $A N C$ absolute neutrophil count, $A U C$ area under the plasma concentration-time curve, $O R$ odds ratio, $O S$ overall survival, $P F S$ progression-free survival, $P K$ pharmacokinetics, $p t(s)$ patient(s)

irinotecan-related toxicities [253, 254], irinotecan pharmacokinetics, or tumor response [253]. The only significant association including UGTIA1*60 was found in a haplotype analysis in which a haplotype consisting of UGT1A $1 * 28, * 93$ and *60 variant alleles was significantly associated with grade 4 neutropenia [255].

Similar to UGT1A1*60, UGT1A1*93 (rs10929302; $-3156 \mathrm{G}>\mathrm{A})$ is also in linkage disequilibrium with UGT1A1*28 [252]. UGT1A1*93 results in reduced UGT1A1 expression and is associated with elevated bilirubin concentrations in patients homozygous for UGT1A1*93 [255]. With an MAF of approximately $30 \%$, this genetic variant is commonly detected in Caucasians and African Americans [252]. Clinically, UGT1A1*93 is associated with increased SN-38 AUC [256], lower neutrophil count [257], increased incidence of hematologic toxicities (including neutropenia) [258, 259], diarrhea [260], and grade 3 vomiting [261]. Moreover, UGT1A1*93 was also part of a haplotype including variant alleles of
$U G T 1 A 1 * 28, * 60$, *93, and $U G T 1 A 7 * 3$, which was associated with increased RR [262]. A prospective trial on genotype-guided irinotecan dosing based on UGT1A1*28 and $U G T 1 A 1 * 93$ genotype status is currently ongoing (trial ID: NTR6612).

\subsection{Associations between Other UGT1A Polymorphisms and Irinotecan Pharmacodynamics: UGT1A7 and UGT1A9}

Compared with patients with $U G T 1 A 9 * 1 / * 1$, individuals carrying the $U G T 1 A 9 * 22$ genotype (T9 > T10; MAF 45\%) show higher enzyme expression and higher SN-38 glucuronidation and are therefore more at risk for diarrhea [263, 264]. Other UGT1A9 variants, UGT1A9*3 (98T> C; MAF $3 \%)$ and $U G T 1 A 9 * 5(766 \mathrm{G}>\mathrm{A} ; \mathrm{MAF} 1 \%)$, are rare in Caucasians and are therefore not likely to significantly affect irinotecan pharmacokinetics and pharmacodynamics in this population [265]. Lower enzyme activity and SN-38 
conjugation is observed in UGT1A7*3 [263] and $U G T 1 A 7 * 4$ polymorphisms [266]. In line with these findings, $U G T 1 A 7 * 3 / * 3$ carriers are at greater risk of adverse events while receiving irinotecan chemotherapy [262, 263]. A haplotype consisting of UGT1A7*3, UGT1A9*1, $U G T 1 A 1 * 28, U G T 1 A 1 * 60$, and $U G T 1 A 1 * 93$ alleles was associated with severe neutropenia in a cohort of 167 colorectal cancer patients treated with FOLFIRI [259]. In the same cohort, $U G T 1 A 7 * 3$ was also part of two other haplotypes, including UGT1A9, UGT1A7, and UGT1A6 variants, associated with an increased risk of grade 3-4 neutropenia (Table 3).

\subsection{Associations between Drug Transporter Polymorphisms and Irinotecan Pharmacokinetics and Pharmacodynamics}

Since both irinotecan and $\mathrm{SN}-38$ are substrates of $\mathrm{ABC}$ transporters (Fig. 2), $A B C$ polymorphisms may also affect irinotecan pharmacokinetics [267], as well as irinotecanrelated toxicities [174]. In a multivariate analysis including $U G T 1 A 1 * 93$, and $A B C C 1$ single nucleotide polymorphisms (SNPs) rs6498588 and rs17501331, these variants were associated with increased SN-38 plasma concentrations and/or decreased absolute neutrophil counts [256]. The opposite effects were reported for the $A B C B 1$ variant rs12720066, which was associated with decreased SN-38 exposure and increased neutrophils. Carriers of another $A B C B 1$ SNP (rs1045642) had an increased risk for early toxicity and lower treatment response [268]. In patients with liver metastases treated with hepatic artery infusion of irinotecan, oxaliplatin and 5-fluorouracil and intravenous cetuximab, this SNP was also associated with toxicity (grade 3-4 neutropenia), increased systemic concentrations of oxaliplatin and cetuximab, and prolonged PFS [269]. Furthermore, carriers of the $A B C B 1$ haplotype (including rs1045642, rs1128503, rs2032582) responded less frequently and had shorter survival [268]. In addition to $A B C B 1$ and $A B C C 1$, polymorphisms of $A B C C 2$ (rs3740066) and $A B C G 2$ (rs2231137) were reported to be independently predictive for toxicity (i.e. grade 3 diarrhea) [264]. In contrast, the $A B C G 2421 \mathrm{C}>\mathrm{A}$ A NP seems to have a limited impact on irinotecan exposure [270]. Polymorphisms in the gene for the hepatic efflux transporter ABCC2 may have a protective effect on diarrhea, which is presumably caused by decreased hepatobiliary transport of irinotecan and therefore reduced irinotecan exposure to the gut [271]. This protective effect was observed in Caucasian patients with the $A B C C 2 * 2$ haplotype (including six ABCC2 variants without any UGT1A1*28 alleles). Although their role in irinotecan efflux has not yet been established, ABCC5 and ABCG1 could also be involved in this process since several SNPs in these transporters are correlated with severe diarrhea [272].

OATP1B1, encoded by the $S L C O 1 B 1$ gene, is involved in the hepatic uptake of SN-38 (Fig. 2). In Caucasian patients carrying at least one $S L C O 1 B 1 * 1 b$ variant allele (rs2306283; MAF 38\%), median neutrophil count increased approximately twofold compared with wild-types [273], presumably by increased hepatic uptake of SN-38, thereby reducing SN-38 plasma concentrations (Table 3). This result confirms an earlier genetic association study on the effects of drug transporters on irinotecan neutropenia and pharmacokinetics [174]. In addition, $S L C O 1 B 1 * 1 b$ was also associated with increased PFS in patients with colorectal and pancreatic cancer [274]. Thus, SLCO1B1*1b could potentially be a protective biomarker for neutropenia and may improve efficacy. In contrast, SLCOIBI*5 (rs4149056) leads to reduced transporter activity and was associated with increased SN-38 plasma concentrations and an increased risk of neutropenia (in combination with UGT1A1*28 variant alleles) [274].

\subsection{Implementation of Genotype-Adjusted Irinotecan Dosing Guidelines}

Both the US FDA and Health Canada/Santé Canada (HCSC) recommend a reduction of the irinotecan starting dose in patients who are homozygous for UGT1A1*28 [275, 276] without specifying the extent of reduction (Table 4). In contrast, the Evaluation of Genomic Applications in Practice and Prevention (EGAPP) Working Group did not find sufficient evidence that UGT1A1 genotyping should be used [277]. However, subsequent guidelines underline the importance of UGT1A1 genotyping, especially for $U G T 1 A 1 * 28$ variant alleles in Western countries. For example, in France and The Netherlands, a reduction of the starting dose of $25-30 \%$ is recommended in patients homozygous for $U G T 1 A 1 * 28$ receiving higher doses of irinotecan $\left(\geq 180 \mathrm{mg} / \mathrm{m}^{2}\right)$ [278, 279]. Regarding liposomal irinotecan, the European Medicines Agency (EMA) recommends an initial dose reduction from 80 to $60 \mathrm{mg} / \mathrm{m}^{2}$ in patients homozygous for UGT1Al*28 [280]. In line with the significant associations between UGT1A $1 * 6$ genotype and irinotecan-induced toxicities in Asian populations, the Japanese Pharmaceuticals and Medical Devices Agency (PMDA) recommends screening patients for $U G T 1 A 1 * 6$ and $* 28$ polymorphisms [281].

Despite the establishment of these guidelines, UGT1A1 genotyping is currently not routinely performed [282], which could be explained by the fact that prospective studies evaluating the clinical effects of genotype-directed dosing are scarce. Most likely, reduction of the irinotecan dose to prevent toxicity in carriers of $U G T 1 A 1 * 1 / * 28$ and UGT1A1*28/*28 is indeed useful since the maximum 
Table 4 Overview of guidelines on pharmacogenetic testing for irinotecan

\begin{tabular}{|c|c|c|c|c|c|c|}
\hline Organization & Country & $\begin{array}{l}\text { Year } \\
\text { of last } \\
\text { update }\end{array}$ & $\begin{array}{l}\text { Genotype } \\
\text { recommended } \\
\text { for testing }\end{array}$ & $\begin{array}{l}\text { Dose reduction } \\
\text { explicitly } \\
\text { recommended? }\end{array}$ & Recommendation & References \\
\hline US FDA & USA & 2014 & $U G T 1 A 1 * 28$ & Yes & $\begin{array}{l}U G T 1 A 1 * 28 / * 28: \text { starting dose } \\
\text { reduction by at least one dose } \\
\text { level }\end{array}$ & {$[275]$} \\
\hline $\begin{array}{l}\text { Health Canada/Santé Canada } \\
\text { (HCSC) }\end{array}$ & Canada & 2014 & $U G T 1 A 1 * 28$ & Yes & $\begin{array}{l}U G T 1 A 1 * 28 / * 28: \text { reduced starting } \\
\text { dose }\end{array}$ & [276] \\
\hline $\begin{array}{l}\text { National Pharmacogenetics } \\
\text { Network (RNPGx) and the } \\
\text { Group of Clinical Onco- } \\
\text { pharmacology (GPCO- } \\
\text { Unicancer) }\end{array}$ & France & 2015 & $U G T 1 A 1 * 28$ & Yes & $\begin{array}{l}U G T 1 A 1 * 28 / * 28 \text { and dose } \\
180-230 \mathrm{mg} / \mathrm{m}^{2}: 25-30 \% \\
\text { reduction of starting dose } \\
U G T 1 A 1 * 28 / * 28 \text { and } \\
\text { dose } \geq 240 \mathrm{mg} / \mathrm{m}^{2}: \text { irinotecan } \\
\text { contraindicated }\end{array}$ & [278] \\
\hline $\begin{array}{l}\text { Royal Dutch Association for the } \\
\text { Advancement of Pharmacy } \\
\text { (KNMP) }\end{array}$ & $\begin{array}{l}\text { The } \\
\text { Netherlands }\end{array}$ & 2011 & $U G T 1 A 1 * 28$ & Yes & $\begin{array}{l}U G T 1 A 1 * 28 / * 28 \text { and } \\
\text { dose }>250 \mathrm{mg} / \mathrm{m}^{2}: \\
30 \% \text { reduction of starting dose }\end{array}$ & [279] \\
\hline $\begin{array}{l}\text { European Medicines Agency } \\
\text { (EMA) }\end{array}$ & Europe & 2017 & $U G T 1 A 1 * 28$ & Yes & $\begin{array}{l}U G T 1 A 1 * 28 / * 28: \text { reduce starting } \\
\text { dose of liposomal irinotecan from } \\
80 \text { to } 60 \mathrm{mg} / \mathrm{m}^{2}\end{array}$ & {$[280]$} \\
\hline $\begin{array}{l}\text { Pharmaceuticals and Medical } \\
\text { Devices Agency (PMDA) }\end{array}$ & Japan & 2014 & $\begin{array}{l}U G T 1 A 1 * 6 \\
\text { and } * 28\end{array}$ & No & $\begin{array}{l}\text { Use irinotecan with caution in } \\
\text { patients with the following } \\
\text { genotypes: } U G T 1 A 1 * 6 / * 6 \text {, } \\
U G T 1 A 1 * 28 / * 28 \text { and } \\
U G T 1 A 1 * 6 / * 28\end{array}$ & [281] \\
\hline
\end{tabular}

tolerated dose of irinotecan was lower in these patients relative to wild-type patients [283]. Whether a dose reduction of irinotecan affects tumor response in $U G T 1 A 1 * 28$ carriers is yet unknown. On the other hand, patients with the $U G T 1 A 1 * 1 / * 1$ or $U G T 1 A 1 * 1 / * 28$ genotype may tolerate higher irinotecan doses than the currently recommended doses and are therefore at risk of suboptimal treatment. Indeed, a phase I dose-finding study convincingly showed that, compared with the recommended irinotecan dose of $180 \mathrm{mg} / \mathrm{m}^{2}$ in the FOLFIRI regimen, substantial higher doses of irinotecan (up to $420 \mathrm{mg} / \mathrm{m}^{2}$ ) were tolerated in patients wild-type or heterozygous for UGT1A1*28 [284]. More recently, similar findings were observed in patients receiving FOLFIRI in combination with bevacizumab [282], implying that the therapeutic window of irinotecan may be increased for the UGTIAl*1/ $* 1$ and $U G T 1 A 1 * 1 / * 28$ genotypes.

In summary, particularly for Caucasians, UGT1A1*28 seems to be a good predictor for neutropenia (all irinotecan doses) and diarrhea (doses $>125 \mathrm{mg} / \mathrm{m}^{2}$ ). UGTIAl $* 28$ is also significantly associated with an increased risk for diarrhea in Asian patients at irinotecan doses $>125 \mathrm{mg} /$ $\mathrm{m}^{2}$. However, in Asian populations the UGTIAl*6 variant is more common and appears to be a more accurate predictor for neutropenia (all irinotecan doses) and diarrhea. In addition to $U G T 1 A 1 * 6$ and $U G T 1 A 1 * 28, U G T 1 A 1 * 93$ is also significantly associated with irinotecan-induced toxicity. Less extensively studied polymorphisms such as $U G T 1 A 7 * 3$ and $U G T 1 A 9 * 1$, and drug transporter polymorphisms ( $A B C B 1, A B C C 5, A B C C 2, A B C G 1, S L C O 1 B 1)$, may also be useful predictors for toxicity. Interestingly, CYP3A4*22 has not been studied thus far, while this SNP has shown relevance for many other CYP3A substrates [285-287]. In order to determine the true value of genotype-driven dosing of irinotecan, the efficacy of this dosing strategy should be evaluated prospectively. The inclusion of additional predictive genetic variants (e.g. UGT1A1*6, *93) in genotype-directed dosing schedules may improve their predictive value.

\section{Conclusions and Future Perspectives}

Irinotecan is a crucial anticancer drug in treatment regimens for several solid tumors. Many factors that contributed to the large interindividual pharmacokinetic variability have been elucidated. In the last decade, much progress has been made in unraveling the pharmacogenetic influence on systemic exposure, toxicity, and survival, however this knowledge has not yet been sufficiently translated into general clinical practice. 
Based on the pharmacokinetic and pharmacogenetic data discussed in this review, we recommend dosing adjustments in the following situations:

- Concomitant use of potent CYP3A4 inducers (e.g. rifampicin, phenytoin, phenobarbital, carbamazepine, SJW): avoid combination.

- Concomitant use of potent CYP3A4 inhibitors (e.g. ketoconazole, itraconazole): avoid combination.

- Caucasians: perform genotyping for UGT1AI*28. Consider at least a $25 \%$ reduction of starting dose in patients homozygous for $U G T 1 A 1 * 28$.

- Asians: perform genotyping for $U G T 1 A 1 * 6$. Consider dose reduction of the starting dose in patients homozygous for $U G T 1 A 1 * 6$. Exact dosing adjustments are as yet unknown.

Future research should prospectively investigate the added value of individualized irinotecan treatment based on patient characteristics, pharmacogenetics, and comedication. Furthermore, novel drug formulations such as liposomal forms of irinotecan could help to pharmacologically optimize irinotecan treatment.

\section{Compliance with Ethical Standards}

Conflicts of interest Femke M. de Man, Andrew K.L. Goey, Ron H.N. van Schaik, Ron H.J. Mathijssen, and Sander Bins declare that they have no conflicts of interest.

Funding This work was not supported by external funding.

Open Access This article is distributed under the terms of the Creative Commons Attribution-NonCommercial 4.0 International License (http://creativecommons.org/licenses/by-nc/4.0/), which permits any noncommercial use, distribution, and reproduction in any medium, provided you give appropriate credit to the original author(s) and the source, provide a link to the Creative Commons license, and indicate if changes were made.

\section{References}

1. Hsiang YH, Liu LF. Identification of mammalian DNA topoisomerase I as an intracellular target of the anticancer drug camptothecin. Cancer Res. 1988;48(7):1722-6.

2. Shao RG, Cao CX, Zhang H, Kohn KW, Wold MS, Pommier Y. Replication-mediated DNA damage by camptothecin induces phosphorylation of RPA by DNA-dependent protein kinase and dissociates RPA:DNA-PK complexes. EMBO J. 1999;18(5):1397-406.

3. Rivory LP, Robert J. Molecular, cellular, and clinical aspects of the pharmacology of 20 (S)camptothecin and its derivatives. Pharmacol Ther. 1995;68(2):269-96.

4. Xie R, Mathijssen RH, Sparreboom A, Verweij J, Karlsson MO. Clinical pharmacokinetics of irinotecan and its metabolites: a population analysis. J Clin Oncol. 2002;20(15):3293-301.

5. Fassberg J, Stella VJ. A kinetic and mechanistic study of the hydrolysis of camptothecin and some analogues. J Pharm Sci. 1992;81(7):676-84.
6. Hertzberg RP, Caranfa MJ, Holden KG, Jakas DR, Gallagher G, Mattern MR, et al. Modification of the hydroxy lactone ring of camptothecin: inhibition of mammalian topoisomerase I and biological activity. J Med Chem. 1989;32(3):715-20.

7. Rivory LP, Chatelut E, Canal P, Mathieu-Boue A, Robert J. Kinetics of the in vivo interconversion of the carboxylate and lactone forms of irinotecan (CPT-11) and of its metabolite SN38 in patients. Cancer Res. 1994;54(24):6330-3.

8. Sasaki Y, Yoshida Y, Sudoh K, Hakusui H, Fujii H, Ohtsu T, et al. Pharmacological correlation between total drug concentration and lactones of CPT-11 and SN-38 in patients treated with CPT-11. Jpn J Cancer Res. 1995;86(1):111-6.

9. Haaz MC, Rivory LP, Riche C, Robert J. The transformation of irinotecan (CPT-11) to its active metabolite $\mathrm{SN}-38$ by human liver microsomes. Differential hydrolysis for the lactone and carboxylate forms. Naunyn Schmiedebergs Arch Pharmacol. 1997;356(2):257-62.

10. Burke TG, Mi Z. The structural basis of camptothecin interactions with human serum albumin: impact on drug stability. J Med Chem. 1994;37(1):40-6.

11. Combes O, Barre J, Duche JC, Vernillet L, Archimbaud Y, Marietta MP, et al. In vitro binding and partitioning of irinotecan (CPT-11) and its metabolite, $\mathrm{SN}-38$, in human blood. Invest New Drugs. 2000;18(1):1-5.

12. Chabot GG, Abigerges D, Catimel G, Culine S, de Forni M, Extra JM, et al. Population pharmacokinetics and pharmacodynamics of irinotecan (CPT-11) and active metabolite SN-38 during phase I trials. Ann Oncol. 1995;6(2):141-51.

13. Klein CE, Gupta E, Reid JM, Atherton PJ, Sloan JA, Pitot HC, et al. Population pharmacokinetic model for irinotecan and two of its metabolites, SN-38 and SN-38 glucuronide. Clin Pharmacol Ther. 2002;72(6):638-47.

14. Poujol S, Pinguet F, Ychou M, Abderrahim AG, Duffour J, Bressolle FM. A limited sampling strategy to estimate the pharmacokinetic parameters of irinotecan and its active metabolite, $\mathrm{SN}-38$, in patients with metastatic digestive cancer receiving the FOLFIRI regimen. Oncol Rep. 2007;18(6):1613-21.

15. Younis IR, Malone S, Friedman HS, Schaaf LJ, Petros WP. Enterohepatic recirculation model of irinotecan (CPT-11) and metabolite pharmacokinetics in patients with glioma. Cancer Chemother Pharmacol. 2009;63(3):517-24.

16. Xie R, Mathijssen RH, Sparreboom A, Verweij J, Karlsson MO. Clinical pharmacokinetics of irinotecan and its metabolites in relation with diarrhea. Clin Pharmacol Ther. 2002;72(3):265-75.

17. Loos WJ, Verweij J, Gelderblom HJ, de Jonge MJ, Brouwer E, Dallaire BK, et al. Role of erythrocytes and serum proteins in the kinetic profile of total 9-amino-20(S)-camptothecin in humans. Anticancer Drugs. 1999;10(8):705-10.

18. Slatter JG, Su P, Sams JP, Schaaf LJ, Wienkers LC. Bioactivation of the anticancer agent CPT-11 to SN-38 by human hepatic microsomal carboxylesterases and the in vitro assessment of potential drug interactions. Drug Metab Dispos. 1997;25(10):1157-64.

19. Morton CL, Wadkins RM, Danks MK, Potter PM. The anticancer prodrug CPT-11 is a potent inhibitor of acetylcholinesterase but is rapidly catalyzed to $\mathrm{SN}-38$ by butyrylcholinesterase. Cancer Res. 1999;59(7):1458-63.

20. Rudakova EV, Boltneva NP, Makhaeva GF. Comparative analysis of esterase activities of human, mouse, and rat blood. Bull Exp Biol Med. 2011;152(1):73-5.

21. Humerickhouse R, Lohrbach K, Li L, Bosron WF, Dolan ME. Characterization of CPT-11 hydrolysis by human liver carboxylesterase isoforms hCE-1 and hCE-2. Cancer Res. 2000;60(5):1189-92. 
22. Bencharit S, Morton CL, Howard-Williams EL, Danks MK, Potter PM, Redinbo MR. Structural insights into CPT-11 activation by mammalian carboxylesterases. Nat Struct Biol. 2002;9(5):337-42.

23. Rivory LP, Bowles MR, Robert J, Pond SM. Conversion of irinotecan (CPT-11) to its active metabolite, 7-ethyl-10-hydroxycamptothecin ( $\mathrm{SN}-38$ ), by human liver carboxylesterase. Biochem Pharmacol. 1996;52(7):1103-11.

24. Nozawa T, Minami H, Sugiura S, Tsuji A, Tamai I. Role of organic anion transporter OATP1B1 (OATP-C) in hepatic uptake of irinotecan and its active metabolite, 7-ethyl-10-hydroxycamptothecin: in vitro evidence and effect of single nucleotide polymorphisms. Drug Metab Dispos. 2005;33(3):434-9.

25. Kawato Y, Furuta T, Aonuma M, Yasuoka M, Yokokura T, Matsumoto K. Antitumor activity of a camptothecin derivative, CPT-11, against human tumor xenografts in nude mice. Cancer Chemother Pharmacol. 1991;28(3):192-8.

26. van Ark-Otte J, Kedde MA, van der Vijgh WJ, Dingemans AM, Jansen WJ, Pinedo HM, et al. Determinants of CPT-11 and SN38 activities in human lung cancer cells. $\mathrm{Br} \mathrm{J}$ Cancer. 1998;77(12):2171-6.

27. Ohtsuka K, Inoue S, Kameyama M, Kanetoshi A, Fujimoto T, Takaoka K, et al. Intracellular conversion of irinotecan to its active form, $\mathrm{SN}-38$, by native carboxylesterase in human nonsmall cell lung cancer. Lung Cancer. 2003;41(2):187-98.

28. Guichard S, Terret C, Hennebelle I, Lochon I, Chevreau P, Fretigny E, et al. CPT-11 converting carboxylesterase and topoisomerase activities in tumour and normal colon and liver tissues. Br J Cancer. 1999;80(3-4):364-70.

29. Xu G, Zhang W, Ma MK, McLeod HL. Human carboxylesterase 2 is commonly expressed in tumor tissue and is correlated with activation of irinotecan. Clin Cancer Res. 2002;8(8):2605-11.

30. Hsieh YT, Lin HP, Chen BM, Huang PT, Roffler SR. Effect of cellular location of human carboxylesterase 2 on CPT-11 hydrolysis and anticancer activity. PLoS One. 2015;10(10):e0141088.

31. Yi BR, Kim SU, Choi KC. Co-treatment with therapeutic neural stem cells expressing carboxyl esterase and CPT-11 inhibit growth of primary and metastatic lung cancers in mice. Oncotarget. 2014;5(24):12835-48.

32. Basel MT, Balivada S, Shrestha TB, Seo GM, Pyle MM, Tamura M, et al. A cell-delivered and cell-activated SN38dextran prodrug increases survival in a murine disseminated pancreatic cancer model. Small. 2012;8(6):913-20.

33. Gutova M, Najbauer J, Chen MY, Potter PM, Kim SU, Aboody KS. Therapeutic targeting of melanoma cells using neural stem cells expressing carboxylesterase, a CPT-11 activating enzyme. Curr Stem Cell Res Ther. 2010;5(3):273-6.

34. Uchino J, Takayama K, Harada A, Sone T, Harada T, Curiel DT, et al. Tumor targeting carboxylesterase fused with anti-CEA $\mathrm{scFv}$ improve the anticancer effect with a less toxic dose of irinotecan. Cancer Gene Ther. 2008;15(2):94-100.

35. Oosterhoff D, Overmeer RM, de Graaf M, van der Meulen IH, Giaccone G, van Beusechem VW, et al. Adenoviral vectormediated expression of a gene encoding secreted, EpCAM-targeted carboxylesterase-2 sensitises colon cancer spheroids to CPT-11. Br J Cancer. 2005;92(5):882-7.

36. Meck MM, Wierdl M, Wagner LM, Burger RA, Guichard SM, Krull EJ, et al. A virus-directed enzyme prodrug therapy approach to purging neuroblastoma cells from hematopoietic cells using adenovirus encoding rabbit carboxylesterase and CPT-11. Cancer Res. 2001;61(13):5083-9.

37. Wierdl M, Morton CL, Weeks JK, Danks MK, Harris LC, Potter PM. Sensitization of human tumor cells to CPT-11 via adenoviral-mediated delivery of a rabbit liver carboxylesterase. Cancer Res. 2001;61(13):5078-82.

38. Choi SS, Yoon K, Choi SA, Yoon SB, Kim SU, Lee HJ. Tumorspecific gene therapy for pancreatic cancer using human neural stem cells encoding carboxylesterase. Oncotarget. 2016;7(46):75319-27.

39. Laizure SC, Herring V, Hu Z, Witbrodt K, Parker RB. The role of human carboxylesterases in drug metabolism: have we overlooked their importance? Pharmacotherapy. 2013;33(2):210-22.

40. Rivory LP, Robert J. Identification and kinetics of a beta-glucuronide metabolite of $\mathrm{SN}-38$ in human plasma after administration of the camptothecin derivative irinotecan. Cancer Chemother Pharmacol. 1995;36(2):176-9.

41. Haaz MC, Rivory L, Jantet S, Ratanasavanh D, Robert J. Glucuronidation of SN-38, the active metabolite of irinotecan, by human hepatic microsomes. Pharmacol Toxicol. 1997;80(2):91-6.

42. Iyer L, King CD, Whitington PF, Green MD, Roy SK, Tephly TR, et al. Genetic predisposition to the metabolism of irinotecan (CPT-11). Role of uridine diphosphate glucuronosyltransferase isoform $1 \mathrm{~A} 1$ in the glucuronidation of its active metabolite (SN38 ) in human liver microsomes. J Clin Invest. 1998;101(4):847-54.

43. Ciotti M, Basu N, Brangi M, Owens IS. Glucuronidation of 7-ethyl-10-hydroxycamptothecin (SN-38) by the human UDPglucuronosyltransferases encoded at the UGT1 locus. Biochem Biophys Res Commun. 1999;260(1):199-202.

44. Strassburg CP, Oldhafer K, Manns MP, Tukey RH. Differential expression of the UGT1A locus in human liver, biliary, and gastric tissue: identification of UGT1A7 and UGT1A10 transcripts in extrahepatic tissue. Mol Pharmacol. 1997;52(2):212-20.

45. Hanioka N, Ozawa S, Jinno H, Ando M, Saito Y, Sawada J. Human liver UDP-glucuronosyltransferase isoforms involved in the glucuronidation of 7-ethyl-10-hydroxycamptothecin. Xenobiotica. 2001;31(10):687-99.

46. Tallman MN, Ritter JK, Smith PC. Differential rates of glucuronidation for 7-ethyl-10-hydroxy-camptothecin (SN-38) lactone and carboxylate in human and rat microsomes and recombinant UDP-glucuronosyltransferase isoforms. Drug Metab Dispos. 2005;33(7):977-83.

47. Rivory LP, Haaz MC, Canal P, Lokiec F, Armand JP, Robert J. Pharmacokinetic interrelationships of irinotecan (CPT-11) and its three major plasma metabolites in patients enrolled in phase I/II trials. Clin Cancer Res. 1997;3(8):1261-6.

48. Wasserman E, Myara A, Lokiec F, Goldwasser F, Trivin F, Mahjoubi M, et al. Severe CPT-11 toxicity in patients with Gilbert's syndrome: two case reports. Ann Oncol. 1997;8(10):1049-51.

49. Santos A, Zanetta S, Cresteil T, Deroussent A, Pein F, Raymond E, et al. Metabolism of irinotecan (CPT-11) by CYP3A4 and CYP3A5 in humans. Clin Cancer Res. 2000;6(5):2012-20.

50. Dodds HM, Haaz MC, Riou JF, Robert J, Rivory LP. Identification of a new metabolite of CPT-11 (irinotecan): pharmacological properties and activation to SN-38. J Pharmacol Exp Ther. 1998;286(1):578-83.

51. Mathijssen RH, de Jong FA, van Schaik RH, Lepper ER, Friberg LE, Rietveld T, et al. Prediction of irinotecan pharmacokinetics by use of cytochrome P450 3A4 phenotyping probes. J Natl Cancer Inst. 2004;96(21):1585-92.

52. van der Bol JM, Mathijssen RH, Creemers GJ, Planting AS, Loos WJ, Wiemer EA, et al. A CYP3A4 phenotype-based dosing algorithm for individualized treatment of irinotecan. Clin Cancer Res. 2010;16(2):736-42. 
53. Sperker B, Backman JT, Kroemer HK. The role of beta-glucuronidase in drug disposition and drug targeting in humans. Clin Pharmacokinet. 1997;33(1):18-31.

54. Fujisawa T, Mori M. Influence of various bile salts on betaglucuronidase activity of intestinal bacteria. Lett Appl Microbiol. 1997;25(2):95-7.

55. Cole CB, Fuller R, Mallet AK, Rowland IR. The influence of the host on expression of intestinal microbial enzyme activities involved in metabolism of foreign compounds. J Appl Bacteriol. 1985;59(6):549-53.

56. Takasuna K, Hagiwara T, Hirohashi M, Kato M, Nomura M, Nagai E, et al. Involvement of beta-glucuronidase in intestinal microflora in the intestinal toxicity of the antitumor camptothecin derivative irinotecan hydrochloride (CPT-11) in rats. Cancer Res. 1996;56(16):3752-7.

57. Kong R, Liu T, Zhu X, Ahmad S, Williams AL, Phan AT, et al. Old drug new use-amoxapine and its metabolites as potent bacterial beta-glucuronidase inhibitors for alleviating cancer drug toxicity. Clin Cancer Res. 2014;20(13):3521-30.

58. de Jong FA, Kehrer DF, Mathijssen RH, Creemers GJ, de Bruijn $\mathrm{P}$, van Schaik RH, et al. Prophylaxis of irinotecan-induced diarrhea with neomycin and potential role for UGT1A $1 * 28$ genotype screening: a double-blind, randomized, placebo-controlled study. Oncologist. 2006;11(8):944-54.

59. Slatter JG, Schaaf LJ, Sams JP, Feenstra KL, Johnson MG, Bombardt PA, et al. Pharmacokinetics, metabolism, and excretion of irinotecan (CPT-11) following I.V. infusion of [(14)C]CPT-11 in cancer patients. Drug Metab Dispos. 2000;28(4):423-33

60. Mathijssen RH, van Alphen RJ, Verweij J, Loos WJ, Nooter K, Stoter G, et al. Clinical pharmacokinetics and metabolism of irinotecan (CPT-11). Clin Cancer Res. 2001;7(8):2182-94.

61. Sugiyama Y, Kato Y, Chu X. Multiplicity of biliary excretion mechanisms for the camptothecin derivative irinotecan (CPT11), its metabolite SN-38, and its glucuronide: role of canalicular multispecific organic anion transporter and P-glycoprotein. Cancer Chemother Pharmacol. 1998;42(Suppl):S44-9.

62. Chu XY, Kato Y, Ueda K, Suzuki H, Niinuma K, Tyson CA, et al. Biliary excretion mechanism of CPT-11 and its metabolites in humans: involvement of primary active transporters. Cancer Res. 1998;58(22):5137-43.

63. Nakatomi K, Yoshikawa M, Oka M, Ikegami Y, Hayasaka S, Sano K, et al. Transport of 7-ethyl-10-hydroxycamptothecin (SN-38) by breast cancer resistance protein $\mathrm{ABCG} 2$ in human lung cancer cells. Biochem Biophys Res Commun. 2001;288(4):827-32.

64. Goldwirt L, Beccaria K, Carpentier A, Farinotti R, Fernandez C. Irinotecan and temozolomide brain distribution: a focus on ABCB1. Cancer Chemother Pharmacol. 2014;74(1):185-93.

65. Rowinsky EK, Grochow LB, Ettinger DS, Sartorius SE, Lubejko BG, Chen TL, et al. Phase I and pharmacological study of the novel topoisomerase I inhibitor 7-ethyl-10-[4-(1-piperidino)-1piperidino]carbonyloxycamptothecin (CPT-11) administered as a ninety-minute infusion every 3 weeks. Cancer Res. 1994;54(2):427-36.

66. de Jonge MJ, Verweij J, de Bruijn P, Brouwer E, Mathijssen $\mathrm{RH}$, van Alphen RJ, et al. Pharmacokinetic, metabolic, and pharmacodynamic profiles in a dose-escalating study of irinotecan and cisplatin. J Clin Oncol. 2000;18(1):195-203.

67. Catimel G, Chabot GG, Guastalla JP, Dumortier A, Cote C, Engel C, et al. Phase I and pharmacokinetic study of irinotecan (CPT-11) administered daily for three consecutive days every three weeks in patients with advanced solid tumors. Ann Oncol. 1995;6(2):133-40.

68. Canal P, Gay C, Dezeuze A, Douillard JY, Bugat R, Brunet R, et al. Pharmacokinetics and pharmacodynamics of irinotecan during a phase II clinical trial in colorectal cancer. Pharmacology and molecular mechanisms group of the European Organization for Research and Treatment of Cancer. J Clin Oncol. 1996;14(10):2688-95.

69. Poujol S, Pinguet F, Malosse F, Astre C, Ychou M, Culine S, et al. Sensitive HPLC-fluorescence method for irinotecan and four major metabolites in human plasma and saliva: application to pharmacokinetic studies. Clin Chem. 2003;49(11):1900-8.

70. Saltz LB, Kanowitz J, Kemeny NE, Schaaf L, Spriggs D, Staton BA, et al. Phase I clinical and pharmacokinetic study of irinotecan, fluorouracil, and leucovorin in patients with advanced solid tumors. J Clin Oncol. 1996;14(11):2959-67.

71. Sparreboom A, de Jonge MJ, de Bruijn P, Brouwer E, Nooter K, Loos WJ, et al. Irinotecan (CPT-11) metabolism and disposition in cancer patients. Clin Cancer Res. 1998;4(11):2747-54.

72. Kehrer DF, Yamamoto W, Verweij J, de Jonge MJ, de Bruijn P, Sparreboom A. Factors involved in prolongation of the terminal disposition phase of SN-38: clinical and experimental studies. Clin Cancer Res. 2000;6(9):3451-8.

73. Mathijssen RH, Verweij J, Loos WJ, de Bruijn P, Nooter K, Sparreboom A. Irinotecan pharmacokinetics-pharmacodynamics: the clinical relevance of prolonged exposure to $\mathrm{SN}-38$. Br J Cancer. 2002;87(2):144-50.

74. Mathijssen RH, Verweij J, de Jonge MJ, Nooter K, Stoter G, Sparreboom A. Impact of body-size measures on irinotecan clearance: alternative dosing recommendations. J Clin Oncol. 2002;20(1):81-7.

75. Berg AK, Buckner JC, Galanis E, Jaeckle KA, Ames MM, Reid JM. Quantification of the impact of enzyme-inducing antiepileptic drugs on irinotecan pharmacokinetics and SN-38 exposure. J Clin Pharmacol. 2015;55(11):1303-12.

76. Gupta E, Mick R, Ramirez J, Wang X, Lestingi TM, Vokes EE, et al. Pharmacokinetic and pharmacodynamic evaluation of the topoisomerase inhibitor irinotecan in cancer patients. J Clin Oncol. 1997;15(4):1502-10.

77. Sparreboom A, Wolff AC, Mathijssen RH, Chatelut E, Rowinsky EK, Verweij J, et al. Evaluation of alternate size descriptors for dose calculation of anticancer drugs in the obese. J Clin Oncol. 2007;25(30):4707-13.

78. de Jong FA, Mathijssen RH, Xie R, Verweij J, Sparreboom A. Flat-fixed dosing of irinotecan: influence on pharmacokinetic and pharmacodynamic variability. Clin Cancer Res. 2004;10(12 Pt 1):4068-71.

79. Soepenberg O, Dumez H, Verweij J, Semiond D, deJonge MJ, Eskens FA, et al. Phase I and pharmacokinetic study of oral irinotecan given once daily for 5 days every 3 weeks in combination with capecitabine in patients with solid tumors. J Clin Oncol. 2005;23(4):889-98.

80. Pitot HC, Adjei AA, Reid JM, Sloan JA, Atherton PJ, Rubin J, et al. A phase I and pharmacokinetic study of a powder-filled capsule formulation of oral irinotecan (CPT-11) given daily for 5 days every 3 weeks in patients with advanced solid tumors. Cancer Chemother Pharmacol. 2006;58(2):165-72.

81. Goff LW, Benson AB 3rd, LoRusso PM, Tan AR, Berlin JD, Denis LJ, et al. Phase I study of oral irinotecan as a single-agent and given sequentially with capecitabine. Invest New Drugs. 2012;30(1):290-8.

82. Wagner LM. Oral irinotecan for treatment of pediatric solid tumors: ready for prime time? Pediatr Blood Cancer. 2010;54(5):661-2.

83. Taylor RR, Tang Y, Gonzalez MV, Stratford PW, Lewis AL. Irinotecan drug eluting beads for use in chemoembolization: in vitro and in vivo evaluation of drug release properties. Eur J Pharm Sci. 2007;30(1):7-14.

84. Martin RC 2nd, Scoggins CR, Tomalty D, Schreeder M, Metzger $\mathrm{T}$, Tatum $\mathrm{C}$, et al. Irinotecan drug-eluting beads in the 
treatment of chemo-naive unresectable colorectal liver metastasis with concomitant systemic fluorouracil and oxaliplatin: results of pharmacokinetics and phase I trial. J Gastrointest Surg. 2012;16(8):1531-8.

85. Rao PP, Pascale F, Seck A, Auperin A, Drouard-Troalen L, Deschamps $\mathrm{F}$, et al. Irinotecan loaded in eluting beads: preclinical assessment in a rabbit VX2 liver tumor model. Cardiovasc Intervent Radiol. 2012;35(6):1448-59.

86. Akinwande O, Dendy M, Ludwig JM, Kim HS. Hepatic intraarterial injection of irinotecan drug eluting beads (DEBIRI) for patients with unresectable colorectal liver metastases: a systematic review. Surg Oncol. 2017;26(3):268-75.

87. Lamb YN, Scott LJ. Liposomal irinotecan: a review in metastatic pancreatic adenocarcinoma. Drugs. 2017;77(7):785-92.

88. Garufi C, Torsello A, Tumolo S, Ettorre GM, Zeuli M, Campanella $\mathrm{C}$, et al. Cetuximab plus chronomodulated irinotecan, 5-fluorouracil, leucovorin and oxaliplatin as neoadjuvant chemotherapy in colorectal liver metastases: POCHER trial. Br J Cancer. 2010;103(10):1542-7.

89. Gholam D, Giacchetti S, Brezault-Bonnet C, Bouchahda M, Hauteville D, Adam R, et al. Chronomodulated irinotecan, oxaliplatin, and leucovorin-modulated 5-Fluorouracil as ambulatory salvage therapy in patients with irinotecan- and oxaliplatin-resistant metastatic colorectal cancer. Oncologist. 2006;11(10):1072-80.

90. Garufi C, Vanni B, Aschelter AM, Zappala AR, Bria E, Nistico $\mathrm{C}$, et al. Randomised phase II study of standard versus chronomodulated CPT-11 plus chronomodulated 5-fluorouracil and folinic acid in advanced colorectal cancer patients. Eur $\mathrm{J}$ Cancer. 2006;42(5):608-16.

91. Ballesta A, Innominato PF, Dallmann R, Rand DA, Levi FA. Systems chronotherapeutics. Pharmacol Rev. 2017;69(2):161-99.

92. Dulong S, Ballesta A, Okyar A, Levi F. Identification of circadian determinants of cancer chronotherapy through in vitro chronopharmacology and mathematical modeling. Mol Cancer Ther. 2015;14(9):2154-64.

93. Levi F, Okyar A, Dulong S, Innominato PF, Clairambault J. Circadian timing in cancer treatments. Annu Rev Pharmacol Toxicol. 2010;50:377-421.

94. Giacchetti S, Cure H, Adenis A, Tubiana N, Vernillet L, Chedouba-Messali L, et al. Chronomodulated (Chrono) irinotecan (CPT) versus standard (STD) infusion in patients (pts) with metastatic colorectal cancer (MCC), a randomized multicenter trial. Eur J Cancer. 2001;37:S309.

95. Said R, Kurzrock R, Naing A, Hong DS, Fu S, Piha-Paul SA, et al. Dose-finding study of hepatic arterial infusion of irinotecan-based treatment in patients with advanced cancers metastatic to the liver. Invest New Drugs. 2015;33(4):911-20.

96. Levi F, Karaboue A, Etienne-Grimaldi MC, Paintaud G, Focan $\mathrm{C}$, Innominato $\mathrm{P}$, et al. Pharmacokinetics of irinotecan, oxaliplatin and 5-fluorouracil during hepatic artery chronomodulated infusion: a translational european OPTILIV Study. Clin Pharmacokinet. 2017;56(2):165-77.

97. van Riel JM, van Groeningen CJ, Kedde MA, Gall H, Leisink JM, Gruia G, et al. Continuous administration of irinotecan by hepatic arterial infusion: a phase I and pharmacokinetic study. Clin Cancer Res. 2002;8(2):405-12.

98. Elias D, Matsuhisa T, Sideris L, Liberale G, Drouard-Troalen L, Raynard B, et al. Heated intra-operative intraperitoneal oxaliplatin plus irinotecan after complete resection of peritoneal carcinomatosis: pharmacokinetics, tissue distribution and tolerance. Ann Oncol. 2004;15(10):1558-65.

99. Elias D, Raynard B, Bonnay M, Pocard M. Heated intra-operative intraperitoneal oxaliplatin alone and in combination with intraperitoneal irinotecan: pharmacologic studies. Eur J Surg Oncol. 2006;32(6):607-13.

100. Ahn BJ, Choi MK, Park YS, Lee J, Park SH, Park JO, et al. Population pharmacokinetics of CPT-11 (irinotecan) in gastric cancer patients with peritoneal seeding after its intraperitoneal administration. Eur J Clin Pharmacol. 2010;66(12):1235-45.

101. Choi MK, Ahn BJ, Yim DS, Park YS, Kim S, Sohn TS, et al. Phase I study of intraperitoneal irinotecan in patients with gastric adenocarcinoma with peritoneal seeding. Cancer Chemother Pharmacol. 2011;67(1):5-11.

102. Cotte E, Passot G, Tod M, Bakrin N, Gilly FN, Steghens A, et al. Closed abdomen hyperthermic intraperitoneal chemotherapy with irinotecan and mitomycin C: a phase I study. Ann Surg Oncol. 2011;18(9):2599-603.

103. Glockzin G, Gerken M, Lang SA, Klinkhammer-Schalke M, Piso P, Schlitt HJ. Oxaliplatin-based versus irinotecan-based hyperthermic intraperitoneal chemotherapy (HIPEC) in patients with peritoneal metastasis from appendiceal and colorectal cancer: a retrospective analysis. BMC Cancer. 2014;14:807.

104. Couteau C, Risse ML, Ducreux M, Lefresne-Soulas F, Riva A, Lebecq A, et al. Phase I and pharmacokinetic study of docetaxel and irinotecan in patients with advanced solid tumors. J Clin Oncol. 2000;18(20):3545-52.

105. de Jonge MJ, Sparreboom A, Planting AS, van der Burg ME, de Boer-Dennert MM, ter Steeg J, et al. Phase I study of 3-week schedule of irinotecan combined with cisplatin in patients with advanced solid tumors. J Clin Oncol. 2000;18(1):187-94.

106. DeVore RF, Johnson DH, Crawford J, Garst J, Dimery IW, Eckardt $\mathrm{J}$, et al. Phase II study of irinotecan plus cisplatin in patients with advanced non-small-cell lung cancer. J Clin Oncol. 1999;17(9):2710-20.

107. Kudoh S, Fukuoka M, Masuda N, Yoshikawa A, Kusunoki Y, Matsui K, et al. Relationship between the pharmacokinetics of irinotecan and diarrhea during combination chemotherapy with cisplatin. Jpn J Cancer Res. 1995;86(4):406-13.

108. Czejka M, Schueller J, Hauer K, Ostermann E. Pharmacokinetics and metabolism of irinotecan combined with capecitabine in patients with advanced colorectal cancer. Anticancer Res. 2005;25(4):2985-90.

109. Delord JP, Pierga JY, Dieras V, Bertheault-Cvitkovic F, Turpin FL, Lokiec F, et al. A phase I clinical and pharmacokinetic study of capecitabine (Xeloda) and irinotecan combination therapy (XELIRI) in patients with metastatic gastrointestinal tumours. Br J Cancer. 2005;92(5):820-6.

110. Rea DW, Nortier JW, Ten Bokkel Huinink WW, Falk S, Richel DJ, Maughan T, et al. A phase I/II and pharmacokinetic study of irinotecan in combination with capecitabine as first-line therapy for advanced colorectal cancer. Ann Oncol. 2005;16(7):1123-32.

111. Goel S, Desai K, Karri S, Gollamudi R, Chaudhary I, Bulgaru A, et al. Pharmacokinetic and safety study of weekly irinotecan and oral capecitabine in patients with advanced solid cancers. Invest New Drugs. 2007;25(3):237-45.

112. Shinkai T, Arioka H, Kunikane H, Eguchi K, Sasaki Y, Tamura $\mathrm{T}$, et al. Phase I clinical trial of irinotecan (CPT-11), 7-ethyl-10[4-(1-piperidino)-1-piperidino]carbonyloxy-camptothecin, and cisplatin in combination with fixed dose of vindesine in advanced non-small cell lung cancer. Cancer Res. 1994;54(10):2636-42.

113. Adjei AA, Klein CE, Kastrissios H, Goldberg RM, Alberts SR, Pitot HC, et al. Phase I and pharmacokinetic study of irinotecan and docetaxel in patients with advanced solid tumors: preliminary evidence of clinical activity. J Clin Oncol. 2000;18(5):1116-23.

114. Masuda N, Fukuoka M, Kudoh S, Matsui K, Kusunoki Y, Takada M, et al. Phase I and pharmacologic study of irinotecan 
and etoposide with recombinant human granulocyte colonystimulating factor support for advanced lung cancer. J Clin Oncol. 1994;12(9):1833-41.

115. Vanhoefer U, Harstrick A, Kohne CH, Achterrath W, Rustum YM, Seeber S, et al. Phase I study of a weekly schedule of irinotecan, high-dose leucovorin, and infusional fluorouracil as first-line chemotherapy in patients with advanced colorectal cancer. J Clin Oncol. 1999;17(3):907-13.

116. Saltz L, Shimada Y, Khayat D. CPT-11 (irinotecan) and 5-fluorouracil: a promising combination for therapy of colorectal cancer. Eur J Cancer. 1996;32A(Suppl 3):S24-31.

117. Wasserman E, Cuvier C, Lokiec F, Goldwasser F, Kalla S, Mery-Mignard D, et al. Combination of oxaliplatin plus irinotecan in patients with gastrointestinal tumors: results of two independent phase I studies with pharmacokinetics. J Clin Oncol. 1999;17(6):1751-9.

118. Ford HE, Cunningham D, Ross PJ, Rao S, Aherne GW, Benepal TS, et al. Phase I study of irinotecan and raltitrexed in patients with advanced gastrointestinal tract adenocarcinoma. $\mathrm{Br} \mathrm{J}$ Cancer. 2000;83(2):146-52.

119. Garcia AA, Pujari M, Jeffers S, Iqbal S, Lenz HJ, Beringer P, et al. Phase I clinical and pharmacokinetic trial of docetaxel and irinotecan administered on a weekly schedule. Cancer Chemother Pharmacol. 2005;56(1):75-82.

120. Ettlinger DE, Mitterhauser M, Wadsak W, Ostermann E, Farkouh A, Schueller J, et al. In vivo disposition of irinotecan (CPT11) and its metabolites in combination with the monoclonal antibody cetuximab. Anticancer Res. 2006;26(2B):1337-41.

121. Denlinger CS, Blanchard R, Xu L, Bernaards C, Litwin S, Spittle C, et al. Pharmacokinetic analysis of irinotecan plus bevacizumab in patients with advanced solid tumors. Cancer Chemother Pharmacol. 2009;65(1):97-105.

122. Horita Y, Yamada Y, Hirashima Y, Kato K, Nakajima T, Hamaguchi $\mathrm{T}$, et al. Effects of bevacizumab on plasma concentration of irinotecan and its metabolites in advanced colorectal cancer patients receiving FOLFIRI with bevacizumab as second-line chemotherapy. Cancer Chemother Pharmacol. 2010;65(3):467-71.

123. Wang D, Braiteh F, Lee JJ, Denlinger CS, Shepard DR, Chaudhary A, et al. Lack of pharmacokinetic drug-drug interaction between ramucirumab and irinotecan in patients with advanced solid tumors. Cancer Chemother Pharmacol. 2016;78(4):727-33.

124. Asai G, Yamamoto N, Kurata T, Tamura K, Uejima H, Nakagawa K, et al. Phase I and pharmacokinetic study of combination chemotherapy using irinotecan and paclitaxel in patients with lung cancer. J Thorac Oncol. 2006;1(3):226-30.

125. Murren JR, Peccerillo K, DiStasio SA, Li X, Leffert JJ, Pizzorno $\mathrm{G}$, et al. Dose escalation and pharmacokinetic study of irinotecan in combination with paclitaxel in patients with advanced cancer. Cancer Chemother Pharmacol. 2000;46(1):43-50.

126. Hotta K, Ueoka H, Kiura K, Tabata M, Kuyama S, Satoh K, et al. A phase I study and pharmacokinetics of irinotecan (CPT11) and paclitaxel in patients with advanced non-small cell lung cancer. Lung Cancer. 2004;45(1):77-84.

127. Yokoo K, Hamada A, Watanabe H, Matsuzaki T, Imai T, Fujimoto $\mathrm{H}$, et al. Involvement of up-regulation of hepatic breast cancer resistance protein in decreased plasma concentration of 7-ethyl-10-hydroxycamptothecin ( $\mathrm{SN}-38)$ by coadministration of S-1 in rats. Drug Metab Dispos. 2007;35(9):1511-7.

128. Yokoo K, Hamada A, Tazoe K, Sasaki Y, Saito H. Effects of oral administration of $\mathrm{S}-1$ on the pharmacokinetics of $\mathrm{SN}-38$, irinotecan active metabolite, in patients with advanced colorectal cancer. Ther Drug Monit. 2009;31(3):400-3.

129. Okamoto H, Nagatomo A, Kunitoh H, Kunikane H, Watanabe K. A phase I clinical and pharmacologic study of a carboplatin and irinotecan regimen combined with recombinant human granulocyte-colony stimulating factor in the treatment of patients with advanced nonsmall cell lung carcinoma. Cancer. 1998;82(11):2166-72.

130. Allegrini G, Di Paolo A, Cerri E, Cupini S, Amatori F, Masi G, et al. Irinotecan in combination with thalidomide in patients with advanced solid tumors: a clinical study with pharmacodynamic and pharmacokinetic evaluation. Cancer Chemother Pharmacol. 2006;58(5):585-93.

131. Villalona-Calero M, Schaaf L, Phillips G, Otterson G, Panico K, Duan W, et al. Thalidomide and celecoxib as potential modulators of irinotecan's activity in cancer patients. Cancer Chemother Pharmacol. 2007;59(1):23-33.

132. Ramirez J, Wu K, Janisch L, Karrison T, House LK, Innocenti F, et al. The effect of thalidomide on the pharmacokinetics of irinotecan and metabolites in advanced solid tumor patients. Cancer Chemother Pharmacol. 2011;68(6):1629-32.

133. van Leeuwen RW, van Gelder T, Mathijssen RH, Jansman FG. Drug-drug interactions with tyrosine-kinase inhibitors: a clinical perspective. Lancet Oncol. 2014;15(8):e315-26.

134. Johnson FM, Krug LM, Tran HT, Shoaf S, Prieto VG, Tamboli $\mathrm{P}$, et al. Phase I studies of imatinib mesylate combined with cisplatin and irinotecan in patients with small cell lung carcinoma. Cancer. 2006;106(2):366-74.

135. Bennouna J, Deslandres M, Senellart H, de Labareyre C, RuizSoto R, Wixon C, et al. A phase I open-label study of the safety, tolerability, and pharmacokinetics of pazopanib in combination with irinotecan and cetuximab for relapsed or refractory metastatic colorectal cancer. Invest New Drugs. 2015;33(1):138-47.

136. Boven E, Massard C, Armand JP, Tillier C, Hartog V, Brega $\mathrm{NM}$, et al. A phase I, dose-finding study of sunitinib in combination with irinotecan in patients with advanced solid tumours. Br J Cancer. 2010;103(7):993-1000.

137. Midgley RS, Kerr DJ, Flaherty KT, Stevenson JP, Pratap SE, Koch KM, et al. A phase I and pharmacokinetic study of lapatinib in combination with infusional 5-fluorouracil, leucovorin and irinotecan. Ann Oncol. 2007;18(12):2025-9.

138. Meyerhardt JA, Clark JW, Supko JG, Eder JP, Ogino S, Stewart $\mathrm{CF}$, et al. Phase I study of gefitinib, irinotecan, 5-fluorouracil and leucovorin in patients with metastatic colorectal cancer. Cancer Chemother Pharmacol. 2007;60(5):661-70.

139. Santoro A, Comandone A, Rimassa L, Granetti C, Lorusso V, Oliva $\mathrm{C}$, et al. A phase II randomized multicenter trial of gefitinib plus FOLFIRI and FOLFIRI alone in patients with metastatic colorectal cancer. Ann Oncol. 2008;19(11):1888-93.

140. Veronese ML, Sun W, Giantonio B, Berlin J, Shults J, Davis L, et al. A phase II trial of gefitinib with 5-fluorouracil, leucovorin, and irinotecan in patients with colorectal cancer. Br J Cancer. 2005;92(10):1846-9.

141. Hofheinz RD, Kubicka S, Wollert J, Arnold D, Hochhaus A. Gefitinib in combination with 5-fluorouracil (5-FU)/folinic acid and irinotecan in patients with 5-FU/oxaliplatin- refractory colorectal cancer: a phase I/II study of the Arbeitsgemeinschaft fur Internistische Onkologie (AIO). Onkologie. 2006;29(12):563-7.

142. Kehrer DF, Mathijssen RH, Verweij J, de Bruijn P, Sparreboom A. Modulation of irinotecan metabolism by ketoconazole. J Clin Oncol. 2002;20(14):3122-9.

143. Richards S, Umbreit JN, Fanucchi MP, Giblin J, Khuri F. Selective serotonin reuptake inhibitor-induced rhabdomyolysis associated with irinotecan. South Med J. 2003;96(10):1031-3.

144. Caraci F, Crupi R, Drago F, Spina E. Metabolic drug interactions between antidepressants and anticancer drugs: focus on selective serotonin reuptake inhibitors and hypericum extract. Curr Drug Metab. 2011;12(6):570-7. 
145. Tanaka E. Clinically significant pharmacokinetic drug interactions between antiepileptic drugs. J Clin Pharm Ther. 1999;24(2):87-92.

146. Mathijssen RH, Sparreboom A, Dumez H, van Oosterom AT, de Bruijn EA. Altered irinotecan metabolism in a patient receiving phenytoin. Anticancer Drugs. 2002;13(2):139-40.

147. Innocenti F, Undevia SD, Ramirez J, Mani S, Schilsky RL, Vogelzang NJ, et al. A phase I trial of pharmacologic modulation of irinotecan with cyclosporine and phenobarbital. Clin Pharmacol Ther. 2004;76(5):490-502.

148. Corona G, Vaccher E, Sandron S, Sartor I, Tirelli U, Innocenti $F$, et al. Lopinavir-ritonavir dramatically affects the pharmacokinetics of irinotecan in HIV patients with Kaposi's sarcoma. Clin Pharmacol Ther. 2008;83(4):601-6.

149. Busti AJ, Hall RG, Margolis DM. Atazanavir for the treatment of human immunodeficiency virus infection. Pharmacotherapy. 2004;24(12):1732-47.

150. van der Bol JM, Visser TJ, Loos WJ, de Jong FA, Wiemer EA, van Aken MO, et al. Effects of methimazole on the elimination of irinotecan. Cancer Chemother Pharmacol. 2011;67(1):231-6.

151. Argiris A, Kut V, Luong L, Avram MJ. Phase I and pharmacokinetic study of docetaxel, irinotecan, and celecoxib in patients with advanced non-small cell lung cancer. Invest New Drugs. 2006;24(3):203-12.

152. Javle MM, Cao S, Durrani FA, Pendyala L, Lawrence DD, Smith PF, et al. Celecoxib and mucosal protection: translation from an animal model to a phase I clinical trial of celecoxib, irinotecan, and 5-fluorouracil. Clin Cancer Res. 2007;13(3):965-71.

153. Xu Y, Kolesar JM, Schaaf LJ, Drengler R, Duan W, Otterson G, et al. Phase I and pharmacokinetic study of mitomycin $\mathrm{C}$ and celecoxib as potential modulators of tumor resistance to irinotecan in patients with solid malignancies. Cancer Chemother Pharmacol. 2009;63(6):1073-82.

154. van der Bol JM, Loos WJ, de Jong FA, van Meerten E, Konings IR, Lam MH, et al. Effect of omeprazole on the pharmacokinetics and toxicities of irinotecan in cancer patients: a prospective cross-over drug-drug interaction study. Eur J Cancer. 2011;47(6):831-8.

155. Richardson MA, Sanders T, Palmer JL, Greisinger A, Singletary SE. Complementary/alternative medicine use in a comprehensive cancer center and the implications for oncology. J Clin Oncol. 2000;18(13):2505-14.

156. Sparreboom A, Cox MC, Acharya MR, Figg WD. Herbal remedies in the United States: potential adverse interactions with anticancer agents. J Clin Oncol. 2004;22(12):2489-503.

157. Goey AK, Beijnen JH, Schellens JH. Herb-drug interactions in oncology. Clin Pharmacol Ther. 2014;95(4):354-5.

158. Mathijssen RH, Verweij J, de Bruijn P, Loos WJ, Sparreboom A. Effects of St. John's wort on irinotecan metabolism. J Natl Cancer Inst. 2002;94(16):1247-9.

159. van Erp NP, Baker SD, Zhao M, Rudek MA, Guchelaar HJ, Nortier JW, et al. Effect of milk thistle (Silybum marianum) on the pharmacokinetics of irinotecan. Clin Cancer Res. 2005;11(21):7800-6.

160. Lin LC, Wang MN, Tsai TH. Food-drug interaction of (-)-epigallocatechin-3-gallate on the pharmacokinetics of irinotecan and the metabolite SN-38. Chem Biol Interact. 2008;174(3):177-82.

161. Mirkov S, Komoroski BJ, Ramirez J, Graber AY, Ratain MJ, Strom SC, et al. Effects of green tea compounds on irinotecan metabolism. Drug Metab Dispos. 2007;35(2):228-33.

162. van der Bol JM, Mathijssen RH, Loos WJ, Friberg LE, van Schaik RH, de Jonge MJ, et al. Cigarette smoking and irinotecan treatment: pharmacokinetic interaction and effects on neutropenia. J Clin Oncol. 2007;25(19):2719-26.
163. Engels FK, de Jong FA, Sparreboom A, Mathot RA, Loos WJ, Kitzen JJ, et al. Medicinal cannabis does not influence the clinical pharmacokinetics of irinotecan and docetaxel. Oncologist. 2007;12(3):291-300.

164. National Institutes of Health. Common terminology criteria for adverse events (CTCAE). Bethesda: National Institutes of Health; 2010.

165. Sobrero AF, Maurel J, Fehrenbacher L, Scheithauer W, Abubakr YA, Lutz MP, et al. EPIC: phase III trial of cetuximab plus irinotecan after fluoropyrimidine and oxaliplatin failure in patients with metastatic colorectal cancer. J Clin Oncol. 2008;26(14):2311-9.

166. Cunningham D, Pyrhonen S, James RD, Punt CJ, Hickish TF, Heikkila R, et al. Randomised trial of irinotecan plus supportive care versus supportive care alone after fluorouracil failure for patients with metastatic colorectal cancer. Lancet. 1998;352(9138):1413-8.

167. Rougier P, Van Cutsem E, Bajetta E, Niederle N, Possinger K, Labianca $\mathrm{R}$, et al. Randomised trial of irinotecan versus fluorouracil by continuous infusion after fluorouracil failure in patients with metastatic colorectal cancer. Lancet. 1998;352(9138):1407-12.

168. Saltz LB, Cox JV, Blanke C, Rosen LS, Fehrenbacher L, Moore $\mathrm{MJ}$, et al. Irinotecan plus fluorouracil and leucovorin for metastatic colorectal cancer. Irinotecan Study Group. N Engl J Med. 2000;343(13):905-14.

169. Douillard JY, Cunningham D, Roth AD, Navarro M, James RD, Karasek $\mathrm{P}$, et al. Irinotecan combined with fluorouracil compared with fluorouracil alone as first-line treatment for metastatic colorectal cancer: a multicentre randomised trial. Lancet. 2000;355(9209):1041-7.

170. Van Cutsem E, Kohne CH, Hitre E, Zaluski J, Chang Chien CR, Makhson A, et al. Cetuximab and chemotherapy as initial treatment for metastatic colorectal cancer. $\mathrm{N}$ Engl $\mathrm{J}$ Med. 2009;360(14):1408-17.

171. Peeters M, Price TJ, Cervantes A, Sobrero AF, Ducreux M, Hotko Y, et al. Randomized phase III study of panitumumab with fluorouracil, leucovorin, and irinotecan (FOLFIRI) compared with FOLFIRI alone as second-line treatment in patients with metastatic colorectal cancer. J Clin Oncol. 2010;28(31):4706-13.

172. Tabernero J, Yoshino T, Cohn AL, Obermannova R, Bodoky G, Garcia-Carbonero $\mathrm{R}$, et al. Ramucirumab versus placebo in combination with second-line FOLFIRI in patients with metastatic colorectal carcinoma that progressed during or after firstline therapy with bevacizumab, oxaliplatin, and a fluoropyrimidine (RAISE): a randomised, double-blind, multicentre, phase 3 study. Lancet Oncol. 2015;16(5):499-508.

173. Van Cutsem E, Tabernero J, Lakomy R, Prenen H, Prausova J, Macarulla T, et al. Addition of aflibercept to fluorouracil, leucovorin, and irinotecan improves survival in a phase III randomized trial in patients with metastatic colorectal cancer previously treated with an oxaliplatin-based regimen. J Clin Oncol. 2012;30(28):3499-506.

174. Innocenti F, Kroetz DL, Schuetz E, Dolan ME, Ramirez J, Relling M, et al. Comprehensive pharmacogenetic analysis of irinotecan neutropenia and pharmacokinetics. J Clin Oncol. 2009;27(16):2604-14.

175. Gandia D, Abigerges D, Armand JP, Chabot G, Da Costa L, De Forni M, et al. CPT-11-induced cholinergic effects in cancer patients. J Clin Oncol. 1993;11(1):196-7.

176. Yumuk PF, Aydin SZ, Dane F, Gumus M, Ekenel M, Aliustaoglu $\mathrm{M}$, et al. The absence of early diarrhea with atropine premedication during irinotecan therapy in metastatic colorectal patients. Int J Colorectal Dis. 2004;19(6):609-10. 
177. Cheng C, Lau JE, Earl MA. Use of atropine-diphenoxylate compared with hyoscyamine to decrease rates of irinotecan-related cholinergic syndrome. J Community Support Oncol. 2015;13(1):3-7.

178. Gupta E, Lestingi TM, Mick R, Ramirez J, Vokes EE, Ratain MJ. Metabolic fate of irinotecan in humans: correlation of glucuronidation with diarrhea. Cancer Res. 1994;54(14):3723-5.

179. Rtibi K, Selmi S, Grami D, Sebai H, Amri M, Marzouki L. Irinotecan chemotherapy-induced intestinal oxidative stress: underlying causes of disturbed mucosal water and electrolyte transport. Pathophysiology. 2017;24(4):275-9.

180. Brandi G, Dabard J, Raibaud P, Di Battista M, Bridonneau C, Pisi AM, et al. Intestinal microflora and digestive toxicity of irinotecan in mice. Clin Cancer Res. 2006;12(4):1299-307.

181. Peterson DE, Bensadoun RJ, Roila F, Group EGW. Management of oral and gastrointestinal mucositis: ESMO Clinical Practice Guidelines. Ann Oncol. 2011;22(6):vi78-84.

182. Lalla RV, Bowen J, Barasch A, Elting L, Epstein J, Keefe DM, et al. MASCC/ISOO clinical practice guidelines for the management of mucositis secondary to cancer therapy. Cancer. 2014;120(10):1453-61.

183. Mick R, Gupta E, Vokes EE, Ratain MJ. Limited-sampling models for irinotecan pharmacokinetics-pharmacodynamics: prediction of biliary index and intestinal toxicity. J Clin Oncol. 1996;14(7):2012-9.

184. Herben VM, Schellens JH, Swart M, Gruia G, Vernillet L, Beijnen $\mathrm{JH}$, et al. Phase I and pharmacokinetic study of irinotecan administered as a low-dose, continuous intravenous infusion over 14 days in patients with malignant solid tumors. J Clin Oncol. 1999;17(6):1897-905.

185. Ohe Y, Sasaki Y, Shinkai T, Eguchi K, Tamura T, Kojima A, et al. Phase I study and pharmacokinetics of CPT-11 with 5-day continuous infusion. J Natl Cancer Inst. 1992;84(12):972-4.

186. de Forni M, Bugat R, Chabot GG, Culine S, Extra JM, Gouyette A, et al. Phase I and pharmacokinetic study of the camptothecin derivative irinotecan, administered on a weekly schedule in cancer patients. Cancer Res. 1994;54(16):4347-54.

187. Abigerges D, Chabot GG, Armand JP, Herait P, Gouyette A, Gandia D. Phase I and pharmacologic studies of the camptothecin analog irinotecan administered every 3 weeks in cancer patients. J Clin Oncol. 1995;13(1):210-21.

188. Rothenberg ML, Eckardt JR, Kuhn JG, Burris HA 3rd, Nelson J, Hilsenbeck SG, et al. Phase II trial of irinotecan in patients with progressive or rapidly recurrent colorectal cancer. J Clin Oncol. 1996;14(4):1128-35.

189. Middleton G, Brown S, Lowe C, Maughan T, Gwyther S, Oliver A, et al. A randomised phase III trial of the pharmacokinetic biomodulation of irinotecan using oral ciclosporin in advanced colorectal cancer: results of the Panitumumab, Irinotecan and Ciclosporin in COLOrectal cancer therapy trial (PICCOLO). Eur J Cancer. 2013;49(16):3507-16.

190. Ychou M, Douillard JY, Rougier P, Adenis A, Mousseau M, Dufour P, et al. Randomized comparison of prophylactic antidiarrheal treatment versus no prophylactic antidiarrheal treatment in patients receiving CPT-11 (irinotecan) for advanced 5-FU-resistant colorectal cancer: an open-label multicenter phase II study. Am J Clin Oncol. 2000;23(2):143-8.

191. Michael M, Brittain M, Nagai J, Feld R, Hedley D, Oza A, et al. Phase II study of activated charcoal to prevent irinotecan-induced diarrhea. J Clin Oncol. 2004;22(21):4410-7.

192. Kee BK, Morris JS, Slack RS, Crocenzi T, Wong L, Esparaz B, et al. A phase II, randomized, double blind trial of calcium aluminosilicate clay versus placebo for the prevention of diarrhea in patients with metastatic colorectal cancer treated with irinotecan. Support Care Cancer. 2015;23(3):661-70.
193. Mori K, Kondo T, Kamiyama Y, Kano Y, Tominaga K. Preventive effect of Kampo medicine (Hangeshashin-to) against irinotecan-induced diarrhea in advanced non-small-cell lung cancer. Cancer Chemother Pharmacol. 2003;51(5):403-6.

194. Flieger D, Klassert C, Hainke S, Keller R, Kleinschmidt R, Fischbach W. Phase II clinical trial for prevention of delayed diarrhea with cholestyramine/levofloxacin in the second-line treatment with irinotecan biweekly in patients with metastatic colorectal carcinoma. Oncology. 2007;72(1-2):10-6.

195. Mego M, Chovanec J, Vochyanova-Andrezalova I, Konkolovsky P, Mikulova M, Reckova M, et al. Prevention of irinotecan induced diarrhea by probiotics: a randomized double blind, placebo controlled pilot study. Complement Ther Med. 2015;23(3):356-62.

196. Takeda Y, Kobayashi K, Akiyama Y, Soma T, Handa S, Kudoh $\mathrm{S}$, et al. Prevention of irinotecan (CPT-11)-induced diarrhea by oral alkalization combined with control of defecation in cancer patients. Int J Cancer. 2001;92(2):269-75.

197. Valenti Moreno V, Brunet Vidal J, Manzano Alemany H, Salud Salvia A, Llobera Serentill M, Cabezas Montero I, et al. Prevention of irinotecan associated diarrhea by intestinal alkalization. A pilot study in gastrointestinal cancer patients. Clin Transl Oncol. 2006;8(3):208-12.

198. Lenfers BH, Loeffler TM, Droege CM, Hausamen TU. Substantial activity of budesonide in patients with irinotecan (CPT11) and 5-fluorouracil induced diarrhea and failure of loperamide treatment. Ann Oncol. 1999;10(10):1251-3.

199. Karthaus M, Ballo H, Abenhardt W, Steinmetz T, Geer T, Schimke J, et al. Prospective, double-blind, placebo-controlled, multicenter, randomized phase III study with orally administered budesonide for prevention of irinotecan (CPT-11)-induced diarrhea in patients with advanced colorectal cancer. Oncology. 2005;68(4-6):326-32.

200. Delioukina ML, Prager D, Parson M, Hecht JR, Rosen P, Rosen LS. Phase II trial of irinotecan in combination with amifostine in patients with advanced colorectal carcinoma. Cancer. 2002;94(8):2174-9.

201. Pan CX, Loehrer P, Seitz D, Helft P, Juliar B, Ansari R, et al. A phase II trial of irinotecan, 5-fluorouracil and leucovorin combined with celecoxib and glutamine as first-line therapy for advanced colorectal cancer. Oncology. 2005;69(1):63-70.

202. Huisman SA, Bijman-Lagcher W, IJzermans JN, Smits R, de Bruin RW. Fasting protects against the side effects of irinotecan but preserves its anti-tumor effect in Apc15lox mutant mice. Cell Cycle. 2015;14(14):2333-9.

203. Huisman SA, de Bruijn P, Ghobadi Moghaddam-Helmantel IM, IJzermans JN, Wiemer EA, Mathijssen RH, et al. Fasting protects against the side effects of irinotecan treatment but does not affect anti-tumour activity in mice. $\mathrm{Br} \mathrm{J}$ Pharmacol. 2016;173(5):804-14.

204. Falcone A, Ricci S, Brunetti I, Pfanner E, Allegrini G, Barbara $\mathrm{C}$, et al. Phase III trial of infusional fluorouracil, leucovorin, oxaliplatin, and irinotecan (FOLFOXIRI) compared with infusional fluorouracil, leucovorin, and irinotecan (FOLFIRI) as first-line treatment for metastatic colorectal cancer: the Gruppo Oncologico Nord Ovest. J Clin Oncol. 2007;25(13):1670-6.

205. Masi G, Vasile E, Loupakis F, Cupini S, Fornaro L, Baldi G, et al. Randomized trial of two induction chemotherapy regimens in metastatic colorectal cancer: an updated analysis. J Natl Cancer Inst. 2011;103(1):21-30.

206. Jang HJ, Kim BJ, Kim JH, Kim HS. The addition of bevacizumab in the first-line treatment for metastatic colorectal cancer: an updated meta-analysis of randomized trials. Oncotarget. 2017;8(42):73009-16.

207. Cremolini C, Loupakis F, Antoniotti C, Lupi C, Sensi E, Lonardi $\mathrm{S}$, et al. FOLFOXIRI plus bevacizumab versus FOLFIRI plus 
bevacizumab as first-line treatment of patients with metastatic colorectal cancer: updated overall survival and molecular subgroup analyses of the open-label, phase 3 TRIBE study. Lancet Oncol. 2015;16(13):1306-15.

208. Saltz LB, Niedzwiecki D, Hollis D, Goldberg RM, Hantel A, Thomas JP, et al. Irinotecan fluorouracil plus leucovorin is not superior to fluorouracil plus leucovorin alone as adjuvant treatment for stage III colon cancer: results of CALGB 89803. J Clin Oncol. 2007;25(23):3456-61.

209. Ychou M, Raoul JL, Douillard JY, Gourgou-Bourgade S, Bugat $\mathrm{R}$, Mineur $\mathrm{L}$, et al. A phase III randomised trial of LV5FU2 + irinotecan versus LV5FU2 alone in adjuvant highrisk colon cancer (FNCLCC Accord02/FFCD9802). Ann Oncol. 2009;20(4):674-80.

210. Fallik D, Borrini F, Boige V, Viguier J, Jacob S, Miquel C, et al. Microsatellite instability is a predictive factor of the tumor response to irinotecan in patients with advanced colorectal cancer. Cancer Res. 2003;63(18):5738-44.

211. Bertagnolli MM, Niedzwiecki D, Compton CC, Hahn HP, Hall M, Damas B, et al. Microsatellite instability predicts improved response to adjuvant therapy with irinotecan, fluorouracil, and leucovorin in stage III colon cancer: cancer and Leukemia Group B Protocol 89803. J Clin Oncol. 2009;27(11):1814-21.

212. Des Guetz G, Uzzan B, Nicolas P, Schischmanoff O, Perret GY, Morere JF. Microsatellite instability does not predict the efficacy of chemotherapy in metastatic colorectal cancer. A systematic review and meta-analysis. Anticancer Res. 2009;29(5):1615-20.

213. Ilson DH, Saltz L, Enzinger P, Huang Y, Kornblith A, Gollub $\mathrm{M}$, et al. Phase II trial of weekly irinotecan plus cisplatin in advanced esophageal cancer. J Clin Oncol. 1999;17(10):3270-5.

214. Pozzo C, Barone C, Szanto J, Padi E, Peschel C, Bukki J, et al. Irinotecan in combination with 5-fluorouracil and folinic acid or with cisplatin in patients with advanced gastric or esophagealgastric junction adenocarcinoma: results of a randomized phase II study. Ann Oncol. 2004;15(12):1773-81.

215. Brell JM, Krishnamurthi SS, Javle M, Saltzman J, Wollner I, Pelley R, et al. A multi-center phase II study of oxaliplatin, irinotecan, and capecitabine in advanced gastric/gastroesophageal junction carcinoma. Cancer Chemother Pharmacol. 2009;63(5):851-7.

216. Lustberg MB, Bekaii-Saab T, Young D, Otterson G, Burak W, Abbas A, et al. Phase II randomized study of two regimens of sequentially administered mitomycin $\mathrm{C}$ and irinotecan in patients with unresectable esophageal and gastroesophageal adenocarcinoma. J Thorac Oncol. 2010;5(5):713-8.

217. Moehler M, Kanzler S, Geissler M, Raedle J, Ebert MP, Daum $\mathrm{S}$, et al. A randomized multicenter phase II study comparing capecitabine with irinotecan or cisplatin in metastatic adenocarcinoma of the stomach or esophagogastric junction. Ann Oncol. 2010;21(1):71-7.

218. Roy A, Cunningham D, Hawkins R, Sorbye H, Adenis A, Barcelo JR, et al. Docetaxel combined with irinotecan or 5-fluorouracil in patients with advanced oesophago-gastric cancer: a randomised phase II study. $\mathrm{Br} \mathrm{J}$ Cancer. 2012;107(3):435-41.

219. Enzinger PC, Kulke MH, Clark JW, Ryan DP, Kim H, Earle CC, et al. A phase II trial of irinotecan in patients with previously untreated advanced esophageal and gastric adenocarcinoma. Dig Dis Sci. 2005;50(12):2218-23.

220. Dank M, Zaluski J, Barone C, Valvere V, Yalcin S, Peschel C, et al. Randomized phase III study comparing irinotecan combined with 5-fluorouracil and folinic acid to cisplatin combined with 5-fluorouracil in chemotherapy naive patients with advanced adenocarcinoma of the stomach or esophagogastric junction. Ann Oncol. 2008;19(8):1450-7.
221. Wagner AD, Syn NL, Moehler M, Grothe W, Yong WP, Tai $\mathrm{BC}$, et al. Chemotherapy for advanced gastric cancer. Cochrane Database Syst Rev. 2017;(8):CD004064. https://doi.org/10. 1002/14651858.CD004064.pub4.

222. Yang XQ, Li CY, Xu MF, Zhao H, Wang D. Comparison of first-line chemotherapy based on irinotecan or other drugs to treat non-small cell lung cancer in stage IIIB/IV: a systematic review and meta-analysis. BMC Cancer. 2015;15:949.

223. Kalemkerian GP. Advances in pharmacotherapy of small cell lung cancer. Expert Opin Pharmacother. 2014;15(16):2385-96.

224. Nakano T, Chahinian AP, Shinjo M, Togawa N, Tonomura A, Miyake M, et al. Cisplatin in combination with irinotecan in the treatment of patients with malignant pleural mesothelioma: a pilot phase II clinical trial and pharmacokinetic profile. Cancer. 1999;85(11):2375-84.

225. Peters KB, Lou E, Desjardins A, Reardon DA, Lipp ES, Miller E, et al. Phase II trial of upfront bevacizumab, irinotecan, and temozolomide for unresectable glioblastoma. Oncologist. 2015;20(7):727-8.

226. Lhomme C, Fumoleau P, Fargeot P, Krakowski Y, Dieras V, Chauvergne J, et al. Results of a European Organization for Research and Treatment of Cancer/Early Clinical Studies Group phase II trial of first-line irinotecan in patients with advanced or recurrent squamous cell carcinoma of the cervix. J Clin Oncol. 1999; 17(10):3136-42.

227. Sugiyama T, Nishida T, Kumagai S, Nishio S, Fujiyoshi K, Okura $\mathrm{N}$, et al. Combination therapy with irinotecan and cisplatin as neoadjuvant chemotherapy in locally advanced cervical cancer. Br J Cancer. 1999;81(1):95-8.

228. Bodurka DC, Levenback C, Wolf JK, Gano J, Wharton JT, Kavanagh JJ, et al. Phase II trial of irinotecan in patients with metastatic epithelial ovarian cancer or peritoneal cancer. J Clin Oncol. 2003;21(2):291-7.

229. Musa F, Pothuri B, Blank SV, Ling HT, Speyer JL, Curtin J, et al. Phase II study of irinotecan in combination with bevacizumab in recurrent ovarian cancer. Gynecol Oncol. 2017;144(2):279-84.

230. Murphy BA, Cmelak A, Burkey B, Netterville J, Shyr Y, Douglas S, et al. Topoisomerase I inhibitors in the treatment of head and neck cancer. Oncology (Williston Park). 2001;15(7 Suppl 8):47-52.

231. Gilbert J, Cmelak A, Shyr Y, Netterville J, Burkey BB, Sinard RJ, et al. Phase II trial of irinotecan plus cisplatin in patients with recurrent or metastatic squamous carcinoma of the head and neck. Cancer. 2008;113(1):186-92.

232. Conroy T, Desseigne F, Ychou M, Bouche O, Guimbaud R, Becouarn Y, et al. FOLFIRINOX versus gemcitabine for metastatic pancreatic cancer. N Engl J Med. 2011;364(19):1817-25.

233. Barbarino JM, Haidar CE, Klein TE, Altman RB. PharmGKB summary: very important pharmacogene information for UGT1A1. Pharmacogenet Genom. 2014;24(3):177-83.

234. Bosma PJ, Chowdhury JR, Bakker C, Gantla S, de Boer A, Oostra BA, et al. The genetic basis of the reduced expression of bilirubin UDP-glucuronosyltransferase 1 in Gilbert's syndrome. N Engl J Med. 1995;333(18):1171-5.

235. Hall D, Ybazeta G, Destro-Bisol G, Petzl-Erler ML, Di Rienzo A. Variability at the uridine diphosphate glucuronosyltransferase 1A1 promoter in human populations and primates. Pharmacogenetics. 1999;9(5):591-9.

236. Beutler E, Gelbart T, Demina A. Racial variability in the UDPglucuronosyltransferase 1 (UGT1A1) promoter: a balanced polymorphism for regulation of bilirubin metabolism? Proc Natl Acad Sci USA. 1998;95(14):8170-4.

237. Akaba K, Kimura T, Sasaki A, Tanabe S, Ikegami T, Hashimoto $\mathrm{M}$, et al. Neonatal hyperbilirubinemia and mutation of the bilirubin uridine diphosphate-glucuronosyltransferase gene: a 
common missense mutation among Japanese, Koreans and Chinese. Biochem Mol Biol Int. 1998;46(1):21-6.

238. Sugatani J, Yamakawa K, Yoshinari K, Machida T, Takagi H, Mori M, et al. Identification of a defect in the UGT1A1 gene promoter and its association with hyperbilirubinemia. Biochem Biophys Res Commun. 2002;292(2):492-7.

239. Wang Y, Shen L, Xu N, Wang JW, Jiao SC, Liu ZY, et al. UGT1A1 predicts outcome in colorectal cancer treated with irinotecan and fluorouracil. World $\mathrm{J}$ Gastroenterol. 2012;18(45):6635-44.

240. Iyer L, Hall D, Das S, Mortell MA, Ramirez J, Kim S, et al. Phenotype-genotype correlation of in vitro SN-38 (active metabolite of irinotecan) and bilirubin glucuronidation in human liver tissue with UGT1A1 promoter polymorphism. Clin Pharmacol Ther. 1999;65(5):576-82.

241. Roncato R, Cecchin E, Montico M, De Mattia E, Giodini L, Buonadonna A, et al. Cost Evaluation of Irinotecan-Related Toxicities Associated With the UGT1A1*28 Patient Genotype. Clin Pharmacol Ther. 2017. https://doi.org/10.1002/cpt.615.

242. Hoskins JM, Goldberg RM, Qu P, Ibrahim JG, McLeod HL. UGT1A1*28 genotype and irinotecan-induced neutropenia: dose matters. J Natl Cancer Inst. 2007;99(17):1290-5.

243. Hu ZY, Yu Q, Pei Q, Guo C. Dose-dependent association between UGT1A1*28 genotype and irinotecan-induced neutropenia: low doses also increase risk. Clin Cancer Res. 2010;16(15):3832-42.

244. Liu X, Cheng D, Kuang Q, Liu G, Xu W. Association of UGT1A1*28 polymorphisms with irinotecan-induced toxicities in colorectal cancer: a meta-analysis in Caucasians. Pharmacogenom J. 2014;14(2):120-9.

245. Chen X, Liu L, Guo Z, Liang W, He J, Huang L, et al. UGT1A1 polymorphisms with irinotecan-induced toxicities and treatment outcome in Asians with Lung Cancer: a meta-analysis. Cancer Chemother Pharmacol. 2017;79(6):1109-17.

246. Chen YJ, Hu F, Li CY, Fang JM, Chu L, Zhang X, et al. The association of UGT1A1*6 and UGT1A1*28 with irinotecaninduced neutropenia in Asians: a meta-analysis. Biomarkers. 2014;19(1):56-62.

247. Han FF, Guo CL, Yu D, Zhu J, Gong LL, Li GR, et al. Associations between UGT1A $1 * 6$ or $\mathrm{UGT} 1 \mathrm{~A} 1 * 6 / * 28$ polymorphisms and irinotecan-induced neutropenia in Asian cancer patients. Cancer Chemother Pharmacol. 2014;73(4):779-88.

248. Cheng L, Li M, Hu J, Ren W, Xie L, Sun ZP, et al. UGT1A1*6 polymorphisms are correlated with irinotecan-induced toxicity: a system review and meta-analysis in Asians. Cancer Chemother Pharmacol. 2014;73(3):551-60.

249. Hu ZY, Yu Q, Zhao YS. Dose-dependent association between UGT1A1 $* 28$ polymorphism and irinotecan-induced diarrhoea: a meta-analysis. Eur J Cancer. 2010;46(10):1856-65.

250. Campbell JM, Stephenson MD, Bateman E, Peters MD, Keefe DM, Bowen JM. Irinotecan-induced toxicity pharmacogenetics: an umbrella review of systematic reviews and meta-analyses. Pharmacogenom J. 2017;17(1):21-8.

251. Dias MM, Pignon JP, Karapetis CS, Boige V, Glimelius B, Kweekel DM, et al. The effect of the UGT1A1*28 allele on survival after irinotecan-based chemotherapy: a collaborative meta-analysis. Pharmacogenom J. 2014;14(5):424-31.

252. Innocenti F, Grimsley C, Das S, Ramirez J, Cheng C, KuttabBoulos H, et al. Haplotype structure of the UDP-glucuronosyltransferase $1 \mathrm{~A} 1$ promoter in different ethnic groups. Pharmacogenetics. 2002;12(9):725-33.

253. Han JY, Lim HS, Shin ES, Yoo YK, Park YH, Lee JE, et al. Comprehensive analysis of UGT1A polymorphisms predictive for pharmacokinetics and treatment outcome in patients with non-small-cell lung cancer treated with irinotecan and cisplatin. J Clin Oncol. 2006;24(15):2237-44.
254. Kim SY, Hong YS, Shim EK, Kong SY, Shin A, Baek JY, et al. S-1 plus irinotecan and oxaliplatin for the first-line treatment of patients with metastatic colorectal cancer: a prospective phase II study and pharmacogenetic analysis. $\mathrm{Br} \mathrm{J}$ Cancer. 2013;109(6):1420-7.

255. Innocenti F, Undevia SD, Iyer L, Chen PX, Das S, Kocherginsky $\mathrm{M}$, et al. Genetic variants in the UDP-glucuronosyltransferase 1A1 gene predict the risk of severe neutropenia of irinotecan. J Clin Oncol. 2004;22(8):1382-8.

256. Li M, Seiser EL, Baldwin RM, Ramirez J, Ratain MJ, Innocenti $\mathrm{F}$, et al. ABC transporter polymorphisms are associated with irinotecan pharmacokinetics and neutropenia. Pharmacogenom J. 2018;18(1):35-42.

257. Bian X, Liu B, Yang Y. Pathological complete response following neoadjuvant radiotherapy and intraperitoneal perfusion chemotherapy for recurrent colon carcinoma: a case report and literature review. Oncol Lett. 2016;11(4):2747-50.

258. Cote JF, Kirzin S, Kramar A, Mosnier JF, Diebold MD, Soubeyran I, et al. UGT1A1 polymorphism can predict hematologic toxicity in patients treated with irinotecan. Clin Cancer Res. 2007;13(11):3269-75.

259. Levesque E, Belanger AS, Harvey M, Couture F, Jonker D, Innocenti F, et al. Refining the UGT1A haplotype associated with irinotecan-induced hematological toxicity in metastatic colorectal cancer patients treated with 5-fluorouracil/irinotecanbased regimens. J Pharmacol Exp Ther. 2013;345(1):95-101.

260. Ferraldeschi R, Minchell LJ, Roberts SA, Tobi S, Hadfield KD, Blackhall $\mathrm{FH}$, et al. UGT1A $1 * 28$ genotype predicts gastrointestinal toxicity in patients treated with intermediate-dose irinotecan. Pharmacogenomics. 2009;10(5):733-9.

261. McLeod HL, Sargent DJ, Marsh S, Green EM, King CR, Fuchs $\mathrm{CS}$, et al. Pharmacogenetic predictors of adverse events and response to chemotherapy in metastatic colorectal cancer: results from North American Gastrointestinal Intergroup Trial N9741. J Clin Oncol. 2010;28(20):3227-33.

262. Cecchin E, Innocenti F, D'Andrea M, Corona G, De Mattia E, Biason P, et al. Predictive role of the UGT1A1, UGT1A7, and UGT1A9 genetic variants and their haplotypes on the outcome of metastatic colorectal cancer patients treated with fluorouracil, leucovorin, and irinotecan. J Clin Oncol. 2009;27(15):2457-65.

263. Inoue K, Sonobe M, Kawamura Y, Etoh T, Takagi M, Matsumura $\mathrm{T}$, et al. Polymorphisms of the UDP-glucuronosyl transferase $1 \mathrm{~A}$ genes are associated with adverse events in cancer patients receiving irinotecan-based chemotherapy. Tohoku J Exp Med. 2013;229(2):107-14.

264. Han JY, Lim HS, Park YH, Lee SY, Lee JS. Integrated pharmacogenetic prediction of irinotecan pharmacokinetics and toxicity in patients with advanced non-small cell lung cancer. Lung Cancer. 2009;63(1):115-20.

265. Paoluzzi L, Singh AS, Price DK, Danesi R, Mathijssen RH, Verweij $\mathbf{J}$, et al. Influence of genetic variants in UGT1A1 and UGT1A9 on the in vivo glucuronidation of SN-38. J Clin Pharmacol. 2004;44(8):854-60.

266. Gagne JF, Montminy V, Belanger P, Journault K, Gaucher G, Guillemette C. Common human UGT1A polymorphisms and the altered metabolism of irinotecan active metabolite 7-ethyl-10hydroxycamptothecin (SN-38). Mol Pharmacol. 2002;62(3):608-17.

267. Mathijssen RH, Marsh S, Karlsson MO, Xie R, Baker SD, Verweij J, et al. Irinotecan pathway genotype analysis to predict pharmacokinetics. Clin Cancer Res. 2003;9(9):3246-53.

268. Glimelius B, Garmo H, Berglund A, Fredriksson LA, Berglund M, Kohnke H, et al. Prediction of irinotecan and 5-fluorouracil toxicity and response in patients with advanced colorectal cancer. Pharmacogenom J. 2011;11(1):61-71. 
269. Levi F, Karaboue A, Saffroy R, Desterke C, Boige V, Smith D, et al. Pharmacogenetic determinants of outcomes on triplet hepatic artery infusion and intravenous cetuximab for liver metastases from colorectal cancer (European trial OPTILIV, NCT00852228). Br J Cancer. 2017;117(7):965-73.

270. de Jong FA, Marsh S, Mathijssen RH, King C, Verweij J, Sparreboom A, et al. ABCG2 pharmacogenetics: ethnic differences in allele frequency and assessment of influence on irinotecan disposition. Clin Cancer Res. 2004;10(17):5889-94.

271. de Jong FA, Scott-Horton TJ, Kroetz DL, McLeod HL, Friberg $\mathrm{LE}$, Mathijssen RH, et al. Irinotecan-induced diarrhea: functional significance of the polymorphic $\mathrm{ABCC} 2$ transporter protein. Clin Pharmacol Ther. 2007;81(1):42-9.

272. Chen S, Villeneuve L, Jonker D, Couture F, Laverdiere I, Cecchin E, et al. ABCC5 and ABCG1 polymorphisms predict irinotecan-induced severe toxicity in metastatic colorectal cancer patients. Pharmacogenet Genom. 2015;25(12):573-83.

273. Crona DJ, Ramirez J, Qiao W, de Graan AJ, Ratain MJ, van Schaik RH, et al. Clinical validity of new genetic biomarkers of irinotecan neutropenia: an independent replication study. Pharmacogenom J. 2016;16(1):54-9.

274. Teft WA, Welch S, Lenehan J, Parfitt J, Choi YH, Winquist E, et al. OATP1B1 and tumour OATP1B3 modulate exposure, toxicity, and survival after irinotecan-based chemotherapy. Br J Cancer. 2015;112(5):857-65.

275. US Food and Drug Administration. Irinotecan hydrochloride. 2014. Available at: https://dailymed.nlm.nih.gov/dailymed/ drugInfo.cfm?setid=e98886aa-933c-430f-bb56-f1eb3862aae4\# boxedwarning.

276. Health Canada/Santé Canada. Product Monograph Camptosar. 2014. Available at: https://api.pharmgkb.org/v1/download/file/ attachment/Irinotecan_HCSC_06_02_15.pdf.

277. Evaluation of Genomic Applications in P. Prevention Working G. Recommendations from the EGAPP Working Group: can UGT1A1 genotyping reduce morbidity and mortality in patients with metastatic colorectal cancer treated with irinotecan? Genet Med. 2009;11(1):15-20.

278. Etienne-Grimaldi MC, Boyer JC, Thomas F, Quaranta S, Picard $\mathrm{N}$, Loriot MA, et al. UGT1A1 genotype and irinotecan therapy: general review and implementation in routine practice. Fundam Clin Pharmacol. 2015;29(3):219-37.

279. Swen JJ, Nijenhuis M, de Boer A, Grandia L, Maitland-van der Zee AH, Mulder $\mathrm{H}$, et al. Pharmacogenetics: from bench to byte-an update of guidelines. Clin Pharmacol Ther. 2011;89(5):662-73.

280. European Medicines Agency. Summary of product characteristics Onivyde (liposomal irinotecan). 2017. Available at: http:// www.ema.europa.eu/docs/en_GB/document_library/EPAR_Product_Information/human/004125/WC500215029.pdf.

281. Pharmaceuticals and Medical Devices Agency (PMDA). PMDA Label for irinotecan and UGT1A1. 2014. Available at: https:// www.apipharmgkborg/v1/download/file/attachment/Irinotecan PMDA_10_31_16pdf.

282. Toffoli G, Sharma MR, Marangon E, Posocco B, Gray E, Mai Q, et al. Genotype-guided dosing study of FOLFIRI plus bevacizumab in patients with metastatic colorectal cancer. Clin Cancer Res. 2017;23(4):918-24.

283. Innocenti F, Schilsky RL, Ramirez J, Janisch L, Undevia S, House LK, et al. Dose-finding and pharmacokinetic study to optimize the dosing of irinotecan according to the UGT1A1 genotype of patients with cancer. J Clin Oncol. 2014;32(22):2328-34.

284. Toffoli G, Cecchin E, Gasparini G, D’Andrea M, Azzarello G, Basso U, et al. Genotype-driven phase I study of irinotecan administered in combination with fluorouracil/leucovorin in patients with metastatic colorectal cancer. J Clin Oncol. 2010;28(5):866-71.

285. Diekstra MH, Klumpen HJ, Lolkema MP, Yu H, Kloth JS, Gelderblom H, et al. Association analysis of genetic polymorphisms in genes related to sunitinib pharmacokinetics, specifically clearance of sunitinib and SU12662. Clin Pharmacol Ther. 2014;96(1):81-9.

286. Wang D, Guo Y, Wrighton SA, Cooke GE, Sadee W. Intronic polymorphism in CYP3A4 affects hepatic expression and response to statin drugs. Pharmacogenom J. 2011;11(4):274-86.

287. Elens L, Bouamar R, Hesselink DA, Haufroid V, van der Heiden IP, van Gelder T, et al. A new functional CYP3A4 intron 6 polymorphism significantly affects tacrolimus pharmacokinetics in kidney transplant recipients. Clin Chem. 2011;57(11):1574-83. 